\title{
Efficient gene targeting by homology-directed repair in rat zygotes using TALE nucleases
}

\author{
Séverine Remy, ${ }^{1,2,7}$ Laurent Tesson, ${ }^{1,2,7}$ Séverine Menoret, ${ }^{1,2}$ Claire Usal, ${ }^{1,2}$ \\ Anne De Cian, ${ }^{3}$ Virginie Thepenier, ${ }^{1,2}$ Reynald Thinard, ${ }^{1,2}$ Daniel Baron, ${ }^{1}$ \\ Marine Charpentier, ${ }^{3}$ Jean-Baptiste Renaud, ${ }^{3}$ Roland Buelow, ${ }^{4}$ Gregory J. Cost, ${ }^{5}$ \\ Carine Giovannangeli, ${ }^{3}$ Alexandre Fraichard, ${ }^{6}$ Jean-Paul Concordet, ${ }^{3}$ and Ignacio Anegon ${ }^{1,2}$ \\ ${ }^{1}$ INSERM UMR 1064-ITUN, CHU de Nantes, Nantes F44093, France; ${ }^{2}$ Platform Rat Transgenesis, Nantes F44093, France; ${ }^{3}$ INSERM \\ U565, CNRS UMR7196, Museum National d'Histoire Naturelle, F75005 Paris, France; ${ }^{4}$ Open Monoclonal Technologies, Palo Alto, \\ California 94303, USA; 5 Sangamo BioSciences, Richmond, California 94804, USA; ${ }^{6}$ genOway, Lyon F69007, France
}

\begin{abstract}
The generation of genetically modified animals is important for both research and commercial purposes. The rat is an important model organism that until recently lacked efficient genetic engineering tools. Sequence-specific nucleases, such as ZFNs, TALE nucleases, and CRISPR/Cas9 have allowed the creation of rat knockout models. Genetic engineering by homology-directed repair (HDR) is utilized to create animals expressing transgenes in a controlled way and to introduce precise genetic modifications. We applied TALE nucleases and donor DNA microinjection into zygotes to generate HDR-modified rats with large new sequences introduced into three different loci with high efficiency $(0.62 \%-5.13 \%$ of microinjected zygotes). Two of these loci (Rosa26 and Hprtl) are known to allow robust and reproducible transgene expression and were targeted for integration of a GFP expression cassette driven by the CAG promoter. GFP-expressing embryos and four Rosa26 GFP rat lines analyzed showed strong and widespread GFP expression in most cells of all analyzed tissues. The third targeted locus was Ighm, where we performed successful exon exchange of rat exon 2 for the human one. At all three loci we observed HDR only when using linear and not circular donor DNA. Mild hypothermic $\left(30^{\circ} \mathrm{C}\right) \mathrm{culture}$ of zygotes after microinjection increased HDR efficiency for some loci. Our study demonstrates that TALE nuclease and donor DNA microinjection into rat zygotes results in efficient and reproducible targeted donor integration by HDR. This allowed creation of genetically modified rats in a work-, cost-, and time-effective manner.
\end{abstract}

[Supplemental material is available for this article.]

Modifying the genome of animals is crucial for an in-depth understanding of physiological and pathophysiological processes as well as for commercial development. Mouse models have traditionally been used in genetics over the past decades, since researchers have in hand all the tools (in particular, embryonic stem [ES] cells) to perform homology-directed repair (HDR) in order to manipulate precisely the genome of this organism (Capecchi 2005). Unfortunately, until recently, HDR-mediated gene targeting was not possible in most other species, including the rat. The rat is a preferred species for studying physiology and certain human pathologies (Jacob 1999, 2010; Jacob and Kwitek 2002). Thus, precise gene targeting technologies would allow many important biomedical questions to be addressed. Despite the recent derivation of rat ES cells (Buehr et al. 2008; Li et al. 2008) to generate knockout (Tong et al. 2010; Yamamoto et al. 2012) and knock-in rats (Meek et al. 2010), rat ES cells are still less robust than mouse ES cells (Zheng et al. 2012). The emergence of engineered nucleases, allowing the rapid and effective generation of genetically modified animals, opens the door to gene targeting in rat but also in other species for which ES cells are not yet available, and provides a faster and more cost-effective strategy compared to the use of ES cells. We and others have shown that zinc finger nucleases (ZFNs) (Geurts et al. 2009; Mashimo et al. 2010), transcription activator-like

\footnotetext{
${ }^{7}$ These authors contributed equally to this work.

Corresponding author: Ignacio.Anegon@univ-nantes.fr

Article published online before print. Article, supplemental material, and publication date are at http://www.genome.org/cgi/doi/10.1101/gr.171538.113.
}

effector (TALE) nucleases (Tesson et al. 2011; Tong et al. 2012; Mashimo et al. 2013), meganucleases (Menoret et al. 2013), and the clustered regularly interspaced short palindromic repeats (CRISPR)-associated protein (Cas) system (Li et al. 2013a,b) are highly and reproducibly effective at disrupting endogenous genes in rat zygotes. Mutations introduced are typically small insertions and/or deletions (indels) that result from imprecise repair of nuclease-induced DNA double-strand breaks by the nonhomologous end joining (NHEJ) mechanism. In addition, the presence of donor DNA allows either the insertion of exogenous genetic information or the replacement of an endogenous sequence by the one of interest. Targeting transgene addition or sequence replacement at loci in the mammalian genome by HDR has been demonstrated using ZFNs in mouse (Meyer et al. 2010; Cui et al. 2011; Meyer et al. 2012), rat (Cui et al. 2011), and rabbit (Flisikowska et al. 2011) zygotes. Gene editing in zygotes using TALE nucleases aimed to introduce point mutations (Wang et al. 2013; Wefers et al. 2013; Ponce de Leon et al. 2014) and, only very recently for the first time, an expression cassette in mice (Sommer et al. 2014).

Even if engineered nucleases stimulate HDR events, the frequency of these events remains rare. Finding methods which could increase the cellular activity of these artificial nucleases may en-

C 2014 Remy et al. This article is distributed exclusively by Cold Spring Harbor Laboratory Press for the first six months after the full-issue publication date (see http://genome.cshlp.org/site/misc/terms.xhtml). After six months, it is available under a Creative Commons License (Attribution-NonCommercial 4.0 International), as described at http://creativecommons.org/licenses/by-nc/4.0/. 
hance rates of HDR. It has been reported that accumulation of nuclease proteins induced by a transient hypothermia enhanced the frequency of gene disruption induced both by ZFNs (Doyon et al. 2010) and by TALE nucleases (Miller et al. 2011) in cell lines, suggesting that this strategy could have beneficial effects on the frequency of HDR events in rat zygotes.

In our study, we applied TALE nucleases to achieve the insertion of a large expression cassette or exon exchange through gene targeting by HDR in rat zygotes. For that purpose, we microinjected TALE nuclease pairs designed to target three loci and the corresponding targeting vectors with regions homologous to the nuclease target site. Two targeted loci (Rosa26 and Hprt1) are known to be permissive for transgene expression, and are therefore ideal candidates to integrate a transgene of interest intended to have stable and ubiquitous expression. Indeed, the Rosa26 locus is commonly used in mice to achieve targeted insertions by HDR using ES cells and has been targeted using ZFNs in mice (Meyer et al. 2010; Hermann et al. 2012). The rat Rosa26 locus was targeted using ES cells (Kobayashi et al. 2012) but not yet using nucleases. Similarly, the Hprt locus is often chosen as a "permissive" locus for targeted integration of transgenes in mouse ES cells (Bronson et al. 1996; Meek et al. 2010). These two loci were chosen to target insertion of a ubiquitous expression cassette encoding GFP, and to assess the potentially beneficial effect of a mild hypothermia treatment on TALE nuclease activity in HDR-mediated transgene integration. The third locus tested was the Ighm locus, for which we achieved efficient rat-to-human exon 2 replacement. The results presented demonstrate that TALE nucleases are efficient tools to insert exogenous genetic information or to replace an endogenous sequence with the one of interest.

\section{Results}

\section{Activity of Hprt1.1, Hprt1.2, and Rosa26 TALE nucleases in cultured rat cells}

We designed pairs of TALE nucleases targeting the rat Hprt1 gene at two different sites (which we refer to as Hprt1.1 and Hprt1.2) within intron 1, or the Rosa26 locus in intron 1, and examined their cleavage activity in cultured rat C6 cells transfected with plasmid DNA encoding individual TALE nucleases. The cleavage activity of the different TALE nuclease pairs was assessed using the T7 endonuclease assay (Fig. 1). We observed 9\%, 15\%, and 13\% of chromosomes bearing nuclease-induced mutations in rat C6 cells transfected with $2 \times 0.75 \mu \mathrm{g}$ Hprt1.1, Hprt1.2, or Rosa26 TALE nuclease pairs, respectively. The frequency of cleavage events increased with higher concentrations $(2 \times 1.5 \mu \mathrm{g})$ of each TALE nuclease pair: 19\% for Hprt1.1, 21\% for Hprt1.2, and 17\% for Rosa26. These results show that all the tested nuclease pairs are active and allowed us to proceed with confidence with experiments in onecell embryos to achieve targeted knock-in events.

\section{Targeting integration into the rat Hprtl and Rosa26 loci}

In order to test whether TALE nucleases could stimulate targeted transgene integration by HDR, we chose to introduce a ubiquitous GFP expression cassette (CAG-GFP-BGHpA) of $3142 \mathrm{bp}$, flanked by $5^{\prime}$ and $3^{\prime}$ homology arms of 800 bp each contiguous to the TALE nuclease cleavage point (Figs. 2A, 3A).

TALE nuclease mRNA and linear donor DNA were co-injected into one-cell stage embryos at different concentrations for the TALE nucleases and at $2 \mathrm{ng} / \mu \mathrm{l}$ for the linear donor DNA (excised ex- pression cassette and homology arms). As previously described (Meyer et al. 2010), a two-step microinjection procedure was performed: The TALE nucleases mRNA and donor DNA mixture were first injected into the male pronucleus and then into the cytoplasm during withdrawal of the injection pipette. We cultured injected embryos at either $37^{\circ} \mathrm{C}$ for $3 \mathrm{~h}$ or $37^{\circ} \mathrm{C}$ for $1 \mathrm{~h}$, followed by $30^{\circ} \mathrm{C}$ for $2 \mathrm{~h}$ or $30^{\circ} \mathrm{C}$ for $3 \mathrm{~h}$ to assess the effect of the temperature on the rate of NHEJ and HDR events. Following this period of culture, surviving zygotes were then transferred into recipient females and genotyping was performed on E15 fetuses or on newborns (Table 1).

When zygotes were injected with the three ratios of Hprt1.1 mRNA/DNA tested, we did not observe significant differences on egg viability $(73.5 \%, 78.5 \%$, and $72.6 \%)$, while a mild decrease in their embryonic development was observed at the highest concentration $(13.3 \%, 10.7 \%$, and $8.2 \%)$. Concerning the Hprt1.2 TALE nucleases, increasing concentrations did not significantly affect zygote viability $(85.8 \%, 72.1 \%$, and $78.3 \%)$ but did impair birth rate at the highest concentration $(26.2 \%$ at $5+5 / 2,20.3 \%$ at $10+10 / 2$, and $0 \%$ at $20+20 / 2 \mathrm{ng} / \mu \mathrm{l})$. Finally, for Rosa26 TALE nucleases, we observed increased toxicity as assayed by zygote viability at higher concentrations (80.8\%, 76.7\%, and 52.2\%); all nuclease concentrations used resulted in similarly lower embryonic development $(9.2 \%, 8.8 \%$, and $10.6 \%)$.

The incubation of embryos at $37^{\circ} \mathrm{C}+30^{\circ} \mathrm{C}$ or $30^{\circ} \mathrm{C}$ after microinjection of Hprt1.2 or Rosa26 TALE nuclease mRNA did not significantly affect either embryo viability or newborn frequencies.

To identify GFP-expressing animals either due to random integration (RI) and/or HDR, E15 fetuses and pups were first exposed to UV light to assay for GFP expression (Table 1). The positive animals were then confirmed by PCR using primers specific for GFP (data not shown). The strategies used to analyze the donor DNA integration into Hprt1 and Rosa26 targeted loci are illustrated in Supplemental Figure S1 and Figures $2 \mathrm{~A}$ and 3A. The animals harboring HDR events were identified by PCR amplification of the $5^{\prime}$ and $3^{\prime}$ junctions between the donor sequence and the target locus (Figs. 2B, 3B; Supplemental Fig. S1B; data not shown). The integrity of the $5^{\prime}$ and 3 ' junctions was confirmed by sequencing (Figs. 2D, 3C; data not shown).

No GFP-expressing animals or animals with donor DNA integration were observed when high concentrations $(20+20$ or $50+$ $50 \mathrm{ng} / \mu \mathrm{l})$ of mRNA encoding Hprt1.1, Hprt1.2, or Rosa26 TALE nucleases were injected, probably at least in part due to toxicity (Table 1). With Hprt1.1, Hprt1.2, or Rosa26 TALE nucleases at a ratio of $10+10 / 2 \mathrm{ng} / \mu \mathrm{l} \mathrm{mRNA} / \mathrm{DNA}\left(37^{\circ} \mathrm{C}\right.$ condition), the frequency of DNA integration reached $1.02 \%, 0.63 \%$, and $3.30 \%$ of transferred embryos, respectively (Table 1 ). In these conditions, junction PCR analyses revealed that one Hprt1.1 (13.1) (Table 2), one Hprt1.2 (6.1) (Table 2), and two Rosa26 (2.1 and 3.1) (Fig. 3B) founders harbored an HDR profile, whereas one Rosa26 was a RI (5.3) (Table 2). Lower concentrations $(5+5 / 2 \mathrm{ng} / \mu \mathrm{l})$ of Hprt1.2 and Rosa26 TALE nucleases were also very efficient at inducing donor DNA integration $(3.17 \%$ and $1.67 \%$ of transferred embryos GFP+, respectively) by HDR (three out of four founders for the Hprt1.2 locus, e.g., 9.6, 11.9, and 12.2, and two founders for the Rosa26 locus, e.g., 10.2 and 12.5) (Tables 1, 2).

Interestingly, using Hprt1.2 TALE nucleases, the HDR frequency of embryos cultured at $37^{\circ} \mathrm{C}$ for $3 \mathrm{~h}(0.63$ and $2.38 \%$ at the dose of $10+10 / 2$ and $5+5 / 2$, respectively) was increased when embryos were maintained either at $37^{\circ} \mathrm{C}$ for $1 \mathrm{~h}+30^{\circ} \mathrm{C}$ for $2 \mathrm{~h}(2.73$ and 2.7 at the dose of $10+10 / 2$ and $5+5 / 2$, respectively) or $30^{\circ} \mathrm{C}$ for $3 \mathrm{~h}(2.54$ and 5.13 at the dose of $10+10 / 2$ and $5+5 / 2$, re- 


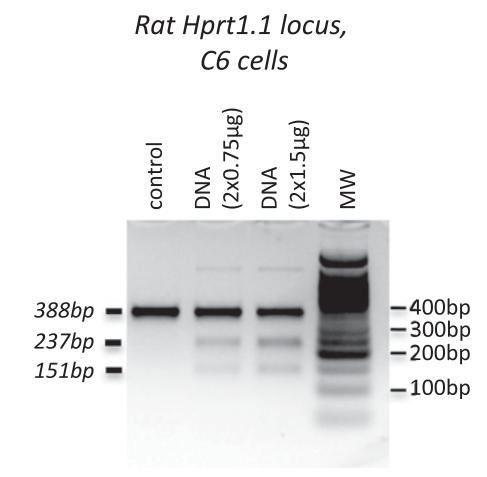

Indels (\%)

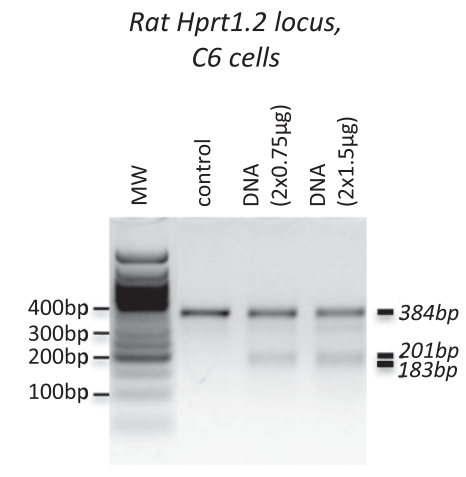

Indels (\%)

$15 \quad 21$

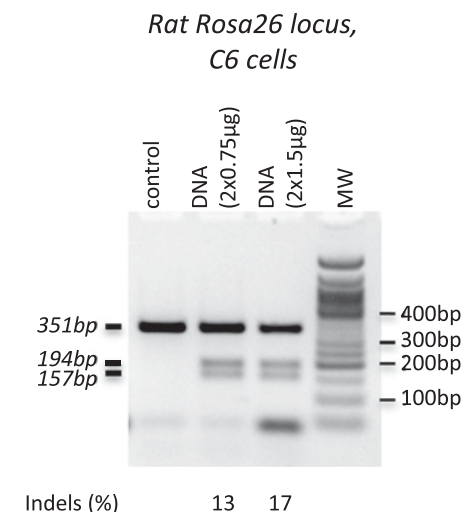

Figure 1. Assay of TALE nucleases for rat Hprt1.1, Hprt1.2, and Rosa26 loci. The frequency of TALE nuclease cleavage was determined using T7 endonuclease assay in C6 cells transfected with the indicated amount of rat Hprt1.1, Hprt1.2, or Rosa26 TALE nuclease expression vectors. Expression vectors without nucleases serve as negative controls. The expected sizes of undigested and digested fragments are indicated in italics. The efficiency of cleavage is indicated below each gel.

spectively) (Table 1). Transient incubation at a lower temperature also tended to increase the frequency of HDR events in the Rosa26 locus: 2.78 at $37^{\circ} \mathrm{C}$ for $1 \mathrm{~h}+30^{\circ} \mathrm{C}$ for $2 \mathrm{~h}$ vs. $1.67 \%$ at $37^{\circ} \mathrm{C}$ but $0 \%$ for $30^{\circ} \mathrm{C}$ incubation (Table 1). The analyses of indel events due to NHEJ at Hprt1.2 and Rosa26 loci showed that their frequency did not vary significantly among the three temperature conditions (Table 1).

RI of the GFP expression cassette (scored as GFP expression and positive PCRs for GFP but with negative $5^{\prime}$ and $3^{\prime}$ junction PCRs) occurred at frequencies similar to those observed when linearized DNA is microinjected for the generation of transgenic rats (0.67\%-2.54\%) (Tesson et al. 2005) and without differences among the different experimental conditions. These RI transgenic animals did not contain HDR events, and for Hprt1.2 TALE nucleases included animals 13.2, 3.2, 5.7, 6.4, 6.5, 7.5, 7.8, 5.1, 9.5, and 10.8 as well as for Rosa26, animals 5.3, 7.1, and 19.3 (Table 2).

To confirm targeted integration of donor DNA by HDR further, we performed Southern blot analyses. All of the 20 animals with the GFP transgene integrated into the Hprt1.2 locus as identified using junction PCR analyses (Figs. 2B,D; Table 2; data not shown), harbored a band of $7.6 \mathrm{~kb}$, consistent with the expected integration mediated by HDR (Fig. 2C; data not shown). The profile on the Southern analysis of some of the animals (animals 2.2 and 5.9 in Fig. 2C) showed a single copy of the expression cassette, whereas that of others (animals 1.2 and 3.4 in Fig. 2C) showed the presence of a band of $4.7 \mathrm{~kb}$ compatible with the presence of more than one copy in concatemers. None of these embryos showed additional bands, indicating that they did not harbor RI copies of the expression cassette. PCR analyses were performed to determine the configuration of these concatemers. For the embryos injected with Hprt1.2 TALE nucleases, all the RI and some of the HDR animals bore integrated concatemers (Table 2 ) in a head-to-tail configuration (Supplemental Fig. S2B) but not in head-to-head or tailto-tail (data not shown).

At the Rosa26 locus, the seven animals for which amplified fragments of expected size and sequence were observed both in 5' and 3' junction PCR analyses (Figs. 3B,C; Table 2; data not shown) showed bands of the expected size (9.2 kb and $2.2 \mathrm{~kb})$, consistent with integration at the target locus by HDR (data not shown). Three of these rats had integration of donor concatemers (Supplemental Fig. S2B) in a head-to-tail configuration but not in head-to-head or tail-to-tail (data not shown).
TALE nuclease-induced DNA cleavage was required for efficient targeted donor DNA integration since the microinjection of $2 \mathrm{ng} / \mathrm{\mu l}$ linear donor DNA alone did not result in any HDR positive animals (Table 1), in accordance with a previous publication that showed a very low level of efficacy $(<0.1 \%)$ for spontaneous HDR in mouse zygotes (Brinster et al. 1989).

We compared the excised linear form of donor DNA vs. the supercoiled form of the plasmid for transgene integration by HDR. As reported in Table 1, of the 25 embryos issued from microinjection of Hprt1.2 TALE nucleases and circular donor DNA, none integrated donor DNA by HDR, and one of them (circ-4.1) (Table 2) integrated the donor DNA by RI. In comparison, in the same conditions $\left(5+5 / 2\right.$ and $30^{\circ} \mathrm{C}$ incubation), when donor DNA was injected in a linear form we obtained eight GFP+ animals (six by HDR, e.g., 1.2, 2.2, 5.9, 9.7, 10.2, and 10.4, and two by RI, e.g., 6.4 and 6.5) (Tables 1,2).

In conclusion, targeted transgene integration could be efficiently achieved in all Hprt1.1, Hprt1.2, and Rosa26 TALE nuclease injections when the concentration of the TALE nuclease was below $10 \mathrm{ng} / \mu \mathrm{l}$. The frequency of mutated animals with indel mutations was higher than that of targeted integration by HDR, consistent with NHEJ being the prevalent mechanism for DNA double-strand break repair. In all founders harboring an HDR-mediated transgene insertion except one (Hprt1.2 1.1) (Table 2), we found a conserved integrated donor DNA and intact 5' and 3' junctions. Transient diminution of temperature and excised linear vs. circular donor DNA tended to increase the frequency of HDR and thus represent alternative methods for gene targeting HDR in rat zygotes that might be superior for certain loci and nuclease pairs.

\section{Efficient germline transmission and expression of donor sequences targeted into the Rosa26 locus}

Five different Rosa26 founders with HDR of the CAG-GFP expression cassette showed germline transmission of the donor sequence with frequencies between $14 \%$ and $46 \%$ (Supplemental Table S1). Figure 3D illustrates two 8-d-old GFP+ animals in the offspring of the animal Rosa26 KI 8.4. Moreover, offspring of each of four Rosa26 HDR+ founders analyzed presented a similar percentage and mean fluorescence intensity of CD45+ GFP+ cells (Fig. 3E). This expression was comparable in animals with one copy (8.4F1, 9.1F1, and 10.2 F1) or with concatemers (12.5F1) (Fig. 3E). Finally, 
A

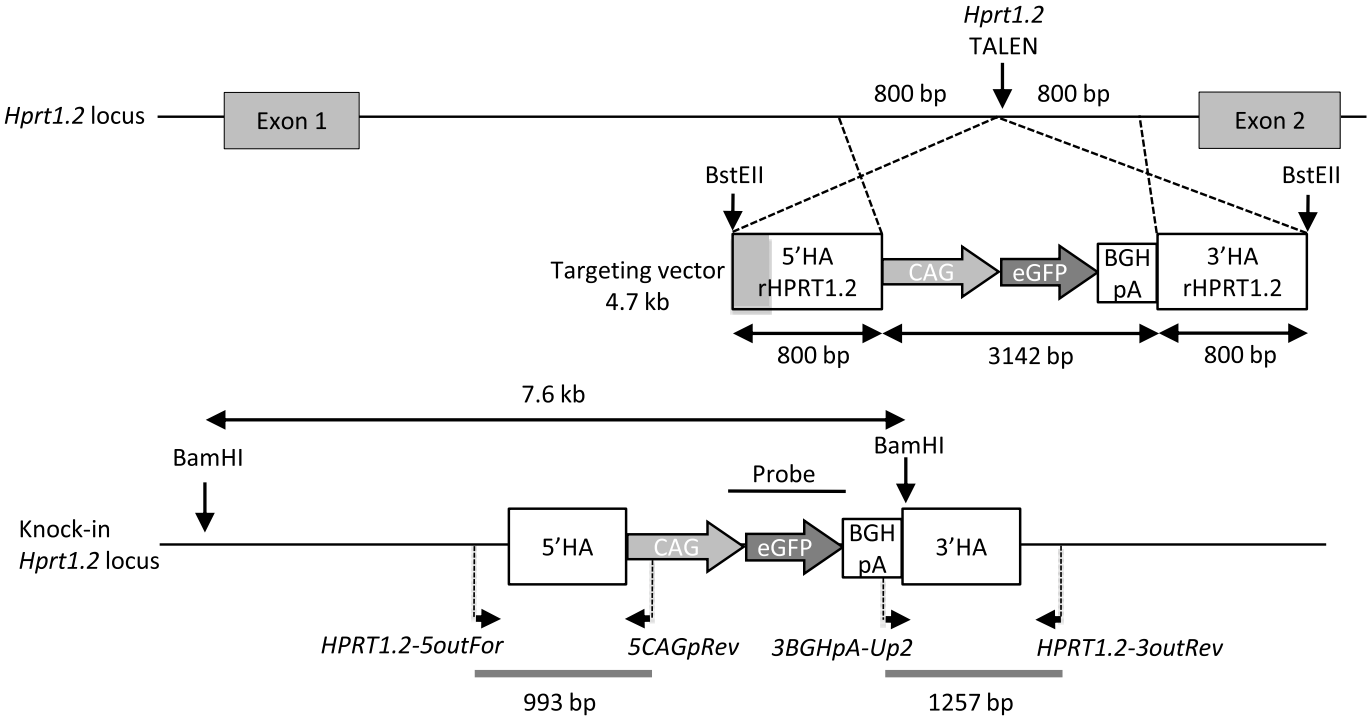

B

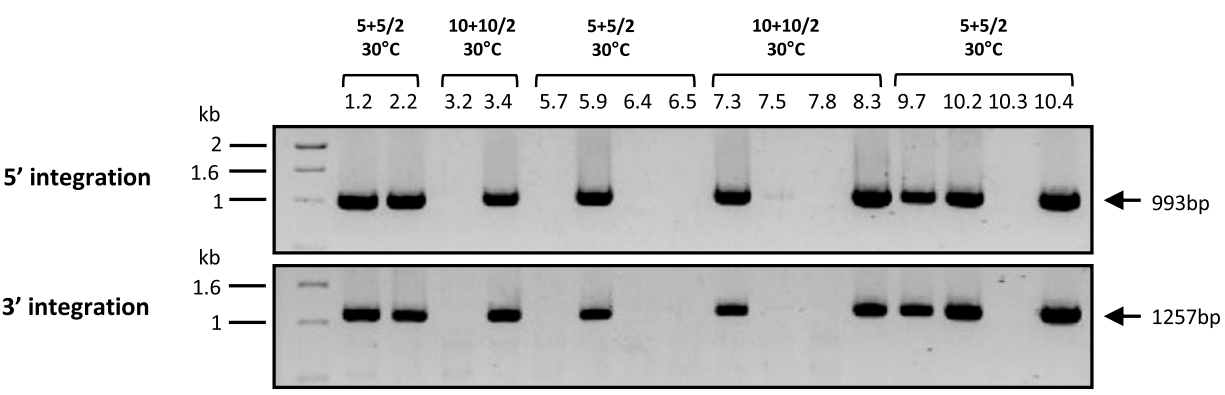

C

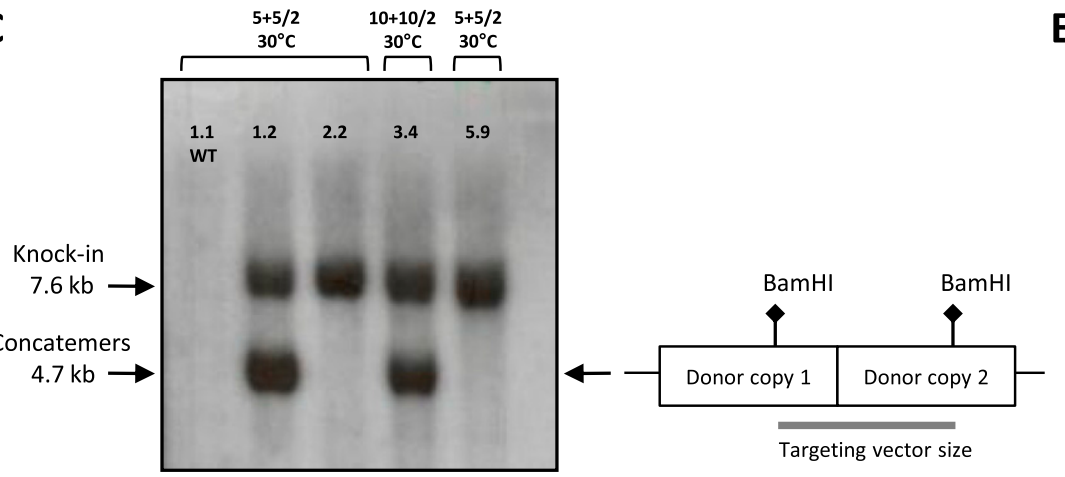

E

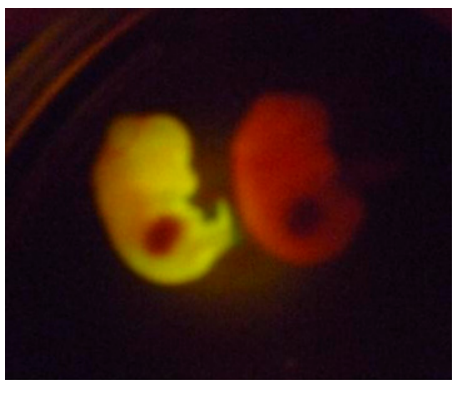

D $\quad 5^{\prime}$ junction

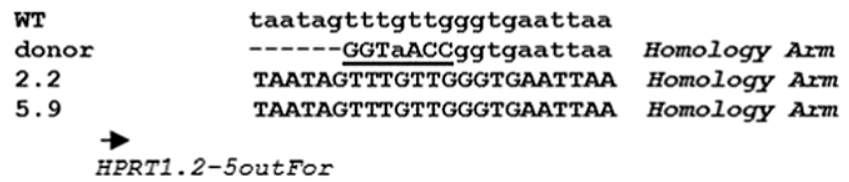

gotaggaataacaaac

getaggGTCGACATTG CAGPEGFPBGHPA

GCTAGGGTCGACATTG CAGPEGFPBGHpA

GCTAGGGTCGACATTG CAGPEGPBGHPA

HPRT1.2-5outFor

5 CAGPRev

$3^{\prime}$ junction

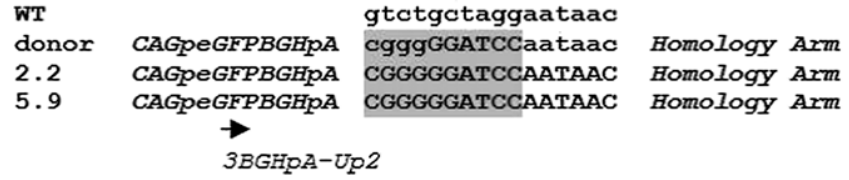

ttaaatgatttttttcct ttaaatGGT tACC-----TTAAATGATTTCTTTTCCT TTAAATGATTTCTTTTCCT

Figure 2. (Legend on next page) 
expression of GFP was uniformly detected in most cells of all tissues analyzed, as shown for liver, kidney, and pancreas (Fig. 3D; data not shown). Expression of GFP in embryos generated with Hprt1.1 and Hprt1.2 TALE nucleases also showed strong and uniform expression upon in toto analysis (Fig. 2E; data not shown). These data provide evidence that integration of the transgene into the Rosa26 locus took place early in development, with low mosaicism and high frequency of transmission to the offspring. Additionally, the integrated transgene into the targeted Rosa26 locus showed high and uniform expression in different lines of transgenic rats, indicating that integration of transgenes into this locus using TALE nucleases is a robust strategy to express transgenes.

\section{Targeted replacement of a rat exon with a human exon at the $\mathrm{Ighm}$ locus}

We aimed to replace an endogenous sequence with an exogenous one since this would allow a wide range of genetic editing applications. As a proof-of-concept model, we applied TALE nucleases targeting the rat Ighm locus used in a previous work (Tesson et al. 2011) to obtain an exon exchange directly in rat zygotes. In the previous study, we showed the cleavage activity of this TALE nuclease pair to be $13 \%$ in rat S16 cells in vitro and $58 \%$ in injected rat zygotes, when delivered as mRNA.

We microinjected sequentially into the pronuclei and cytoplasm of rat zygotes TALE nuclease mRNA directed to sequences in exon 2 of the rat $I g h m$ locus, together with donor DNA sequences containing the exon 2 of human IGHM (71\% homology vs. rat) and homology arms ( 0.75 and $1.46 \mathrm{~kb}$ for $5^{\prime}$ and 3 ' arms, respectively) of rat genomic sequence (Fig. 4A). The homology arms were separated from the TALE nucleases cleavage site by $\sim 150 \mathrm{bp}$. With this transgene donor, successful exon replacement requires spontaneous cellular trimming of at least one of the $3^{\prime}$ single-stranded ends so that the $3^{\prime}$ end terminates in a region of homology with the donor. The microinjection statistics are summarized in Table 3. Microinjection with the supercoiled donor plasmid (410 zygotes) or linearized donor sequences (1063 zygotes) resulted in both cases in normal embryo survival $(75.1 \%$ and $72.7 \%$ of microinjected embryos) and normal numbers of newborn animals $(22.9 \%$ and $15.8 \%$ of transferred embryos). Microinjection of TALE nucleases plus the supercoiled plasmid donor DNA did not result in any donor integration by HDR, but two transgenic animals carrying RI could be detected (Tables 3,4). Microinjection of TALE nucleases plus the linear donor DNA resulted in eight animals (Table 3) with
RI of linear donor DNA $(8,44,49,55,56,63,68$, and 69) (Table 4) and in one embryo (E3) and two founders (53 and 54) with bona fide targeted integration by HDR ( $0.62 \%$ of the transferred zygotes) since they showed $5^{\prime}$ and $3^{\prime}$ flanking PCRs of the expected size and with intact sequences (Figs. 4B,C) as well as the expected 3.2-kb band on the Southern blot (Fig. 4D). Southern blot analysis showed the presence of donor concatemers at the integration site in one founder (53), whereas the other founder (54) had one copy (Fig. 4D) and embryo E3 showed concatemers (data not shown). PCR analysis of concatemers showed that they were orientated in a head-to-tail orientation (Supplemental Fig. S2D).

Founder 54 was mated and transmitted the transgene to six out of 17 pups (Supplemental Table S1). mRNA products containing rat and human sequences were detected in the offspring by RT-PCRs of the expected size (Fig. 4E; data not shown) and contained intact rat and human sequences (data not shown). These F1 heterozygous animals were mated to obtain homozygous F2 animals which did not show the presence of wild-type rat $\mathrm{CH} 2$ sequences, having both alleles replaced with human sequences (data not shown).

Thus, injection of TALE nucleases mRNAs and linear donor DNA with human sequences resulted in the replacement of rat by human IGHM sequences by HDR.

\section{Discussion}

ZFNs were used to obtain transgene targeted integration in previous studies in mice (Meyer et al. 2010, 2012; Cui et al. 2011), rats (Cui et al. 2011), and rabbits (Flisikowska et al. 2011). Compared to ZFNs, TALE nucleases can be designed with somewhat fewer positional constraints (Miller et al. 2011), allowing targeting of virtually any sequences, with high activities and very low off-target effects (for review, see Segal and Meckler 2013). TALE nucleases were applied to achieve targeted gene addition of point mutations in rodents (Panda et al. 2013; Wang et al. 2013; Wefers et al. 2013; Ponce de Leon et al. 2014) and (after the submission of this manuscript) in mice using an expression cassette (Sommer et al. 2014).

Here, we used newly generated TALE nucleases for the Hprt1 and Rosa26 loci and the previously described TALE nucleases for Ighm (Tesson et al. 2011). For the Hprt1 and Rosa26 TALE nucleases, we observed that the correlations between in vitro and in vivo efficiency activities are such that Hprt1.2 > Rosa26 $>$ Hprt1.1. Direct comparison of in vitro efficiencies between Hprt1 and Rosa26 TALE

\footnotetext{
Figure 2. Targeted integration of a GFP cassette into the Hprt1.2 locus. (A) (Upper) Diagram showing schematic representation of the rat Hprt1.2 locus, with the site of TALE nuclease action (vertical arrows), and of the targeting vector with the expression cassette CAG-eGFP-BGHpA (3142 bp) and the 5 ' and 3' homology arms (800 bp each). The homology arms are contiguous to the TALE nucleases' cleavage point. (Gray) The sequence overlap (433 bp) between 3' HArHPRT1.1 (cf. Supplemental Fig. S1) and 5' HArHPRT1.2. BstEll restriction sites are indicated. (A) (Lower) Diagram showing schematic representation of the GFP cassette integration. For flanking PCR analysis, genomic DNA was PCR-amplified with primers situated for the $5^{\prime}$ side: upstream of the 5' HA arm (HPRT1.2-5outFor) and in the CAG promoter (5CAGpRev); and for the 3' side: in the BGHpA (3BGHpA-Up2) and downstream from the 3' HA arm (HPRT1.2-3out Rev). The position of each primer and the corresponding expected size of PCR products are indicated on the schematic knock-in Hprt1.2 locus. For Southern blot analysis, genomic DNA was digested with BamHI and was probed with a GFP probe. A unique band at $7.6 \mathrm{~kb}$ is predicted for a correct HDR into the Hprt1.2 locus. (B) Flanking PCR analysis. Gels show the results of analyzing the $5^{\prime}$ and the $3^{\prime}$ extremities of GFP integration into the Hprt1.2 locus. A representative panel of 16 animals is illustrated, showing the expected bands of 993 bp using the 5' pair of primers (HPRT1.2-5outFor + 5CAGpRev) and of $1257 \mathrm{bp}$ using the 3' pair of primers (3BGHpA-Up2 + HPRT1.2-3outRev). The microinjection conditions in terms of mRNA and DNA concentrations, as well as embryo incubation temperatures, are above each animal. (C) Southern blot analysis following BamH1 DNA digestion for the analysis of transgene site-specific integration into the Hprt1.2 locus using a GFP probe. Four Hprt1.2-GFP+ rats with positive junction PCRs showing a unique band at $7.6 \mathrm{~kb}$ for a HDR with a single copy of the transgene, or $7.6 \mathrm{~kb}$ and $4.7 \mathrm{~kb}$ (the size of the transgene) bands when HDR involved transgene concatemers. The diagram at the right explains the expected size of the concatemers once linearized. The absence of additional bands demonstrates that there are no RI integration events in these animals. As a negative control, an offspring rat with no GFP expression and negative for GFP PCR (1.1) showed no bands. (D) Sequence comparison at the $5^{\prime}$ and $3^{\prime}$ junctions, with wild-type genomic DNA and donor DNA sequences, of two representative embryos (2.2 and 5.9). In donor DNA, the presence of the BstEll site is indicated in $5^{\prime}$ and $3^{\prime}$ (underlined). The $5^{\prime}$ and $3^{\prime}$ ends of the expression cassette are colored in gray. (E) Representative E15 Hprt1.2 HDR-GFP embryos using a Dark Reader Spot Lamp.
} 


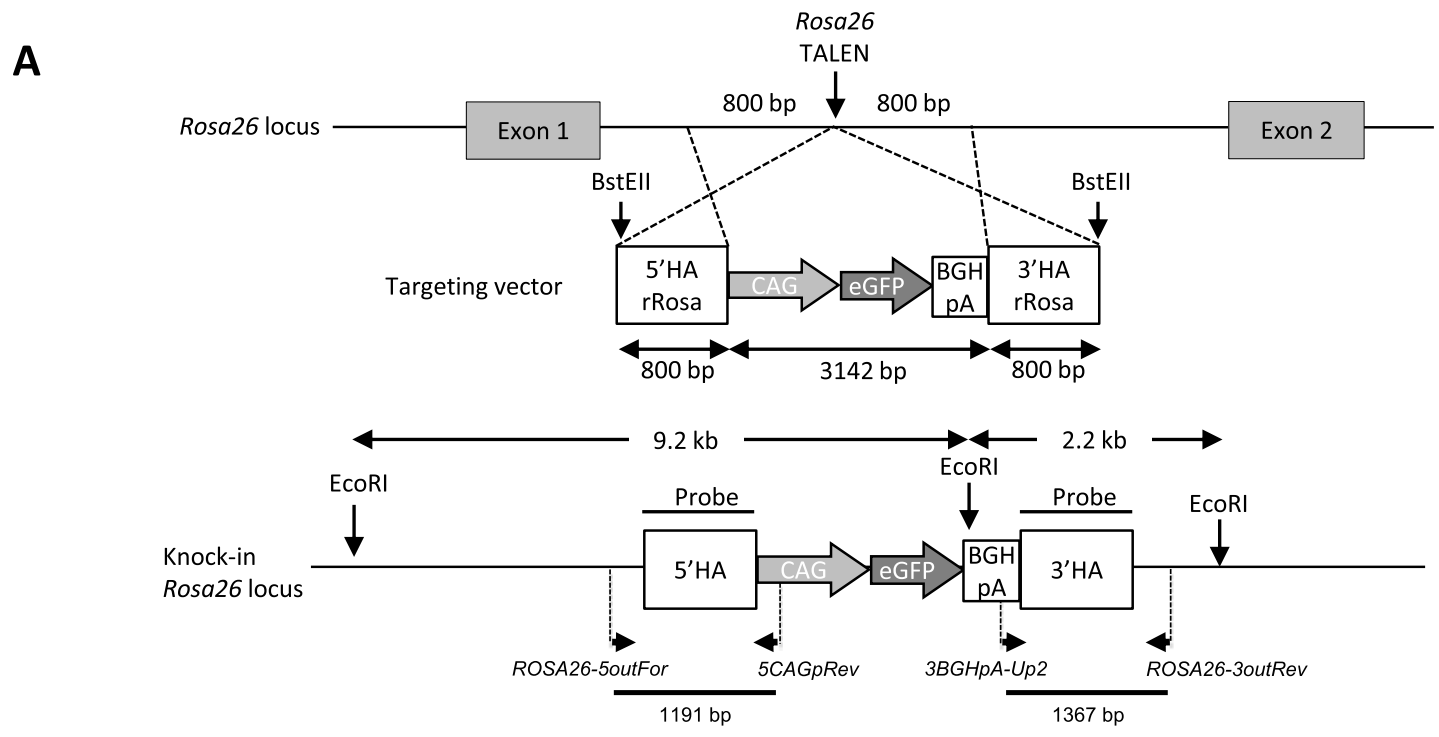

B

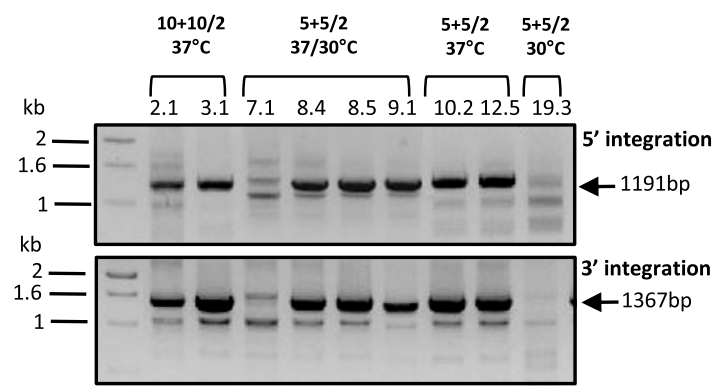

C

5 junction

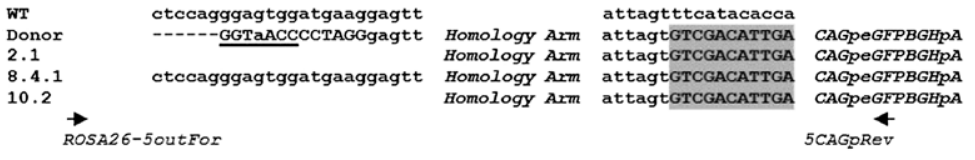

$3^{\prime}$ junction

WT gacagattagtttcat aatgtatttgtgaagcttggttt Donor CAGPeGPPBGHPA AGCCCAAGCTTttcat Homology Arm aatgtCCTAGGGGTtACC----8.4.1 CAGPeGFPBGHPA AGCCCAAGCTTt tcat HomologY Axm AATGTATTTGTGAAGCTTGGTTT 10.2 CAGPeGFPBGHDA AGCCCAAGCTTttcat Homology Arm AATGTATTTGTGAAGCTTGGTTT

$$
\overrightarrow{3 B G H P A-U D 2}
$$

ROSA26-3outRev

D
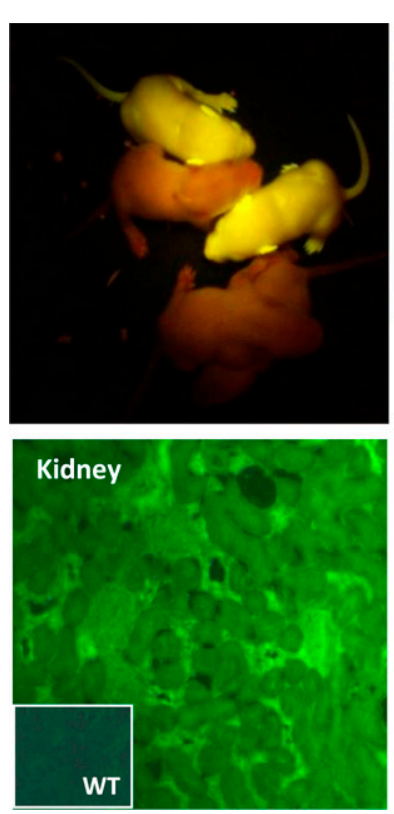

E
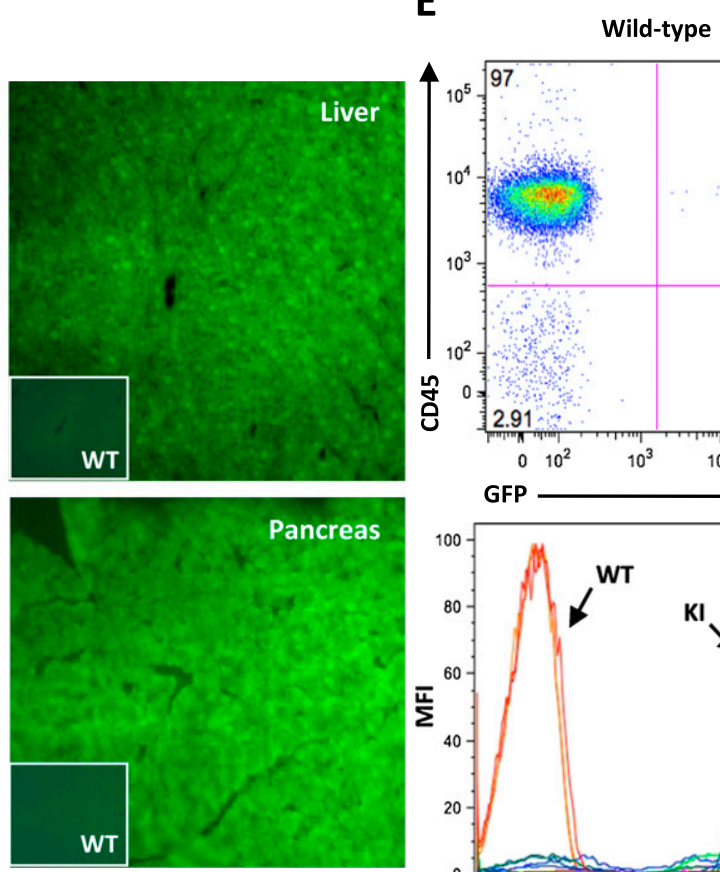
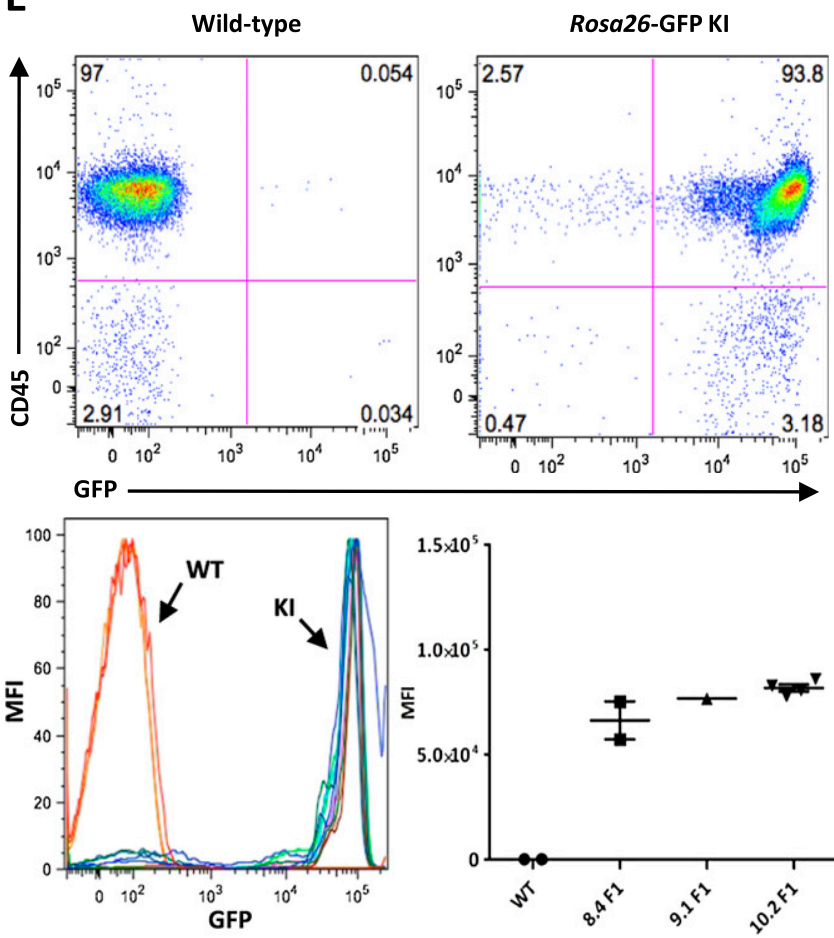

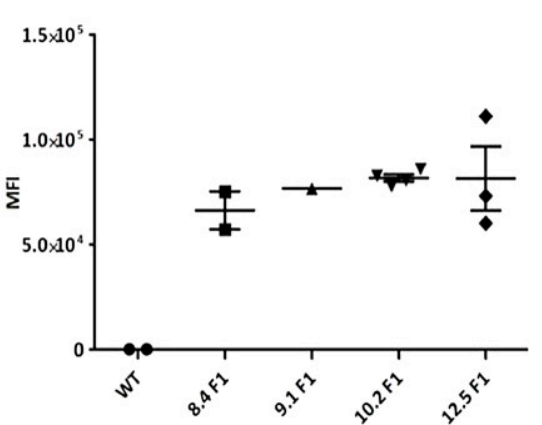

Figure 3. (Legend on next page) 
nucleases with those of Ighm is difficult since they were transfected in different cell lines.

The efficiency of TALE nuclease-mediated HDR seemed to depend primarily on the efficiency of DNA cleavage by the nuclease and not on the type of locus targeted in terms of expression and chromatin status, since Hprt1 and Rosa26 are expressed in the injected zygote, whereas Ighm is not. This conclusion is also substantiated by experiments that we performed using a ZFN for the Ighm locus with lower nuclease activity ( $2 \%$ in C6 cells and $1.5 \%$ of NHEJ following mRNA microinjection) for the exchange of rat by human exon 2 in the Ighm locus (same donor DNA as used for the TALE nucleases) that did not result in HDR events (data not shown).

The frequencies of HDR obtained in the present study were between $0.62 \%$ and $5.13 \%$ of microinjected embryos for the best conditions. Despite differences in the models that make direct comparisons only relative, these frequencies are comparable to the ones for targeted insertion using TALE nucleases and ssODN donors ranging from $1.8 \%$ to $6.8 \%$ in mouse embryos (Panda et al. 2013; Wefers et al. 2013) but higher than the ones obtained with an expression cassette $(2 / 900,0.22 \%)$ (Sommer et al. 2014). The frequencies obtained in our study are also comparable to the ones observed using ZFN mRNA for HDR in rats $(2.4 \%$ and $8.3 \%$ for two different loci) (Cui et al. 2011) and mice (1.7\% and 5\% for two different loci) (Meyer et al. 2010; Cui et al. 2011). In this report, as well as in others using ZFNs, TALE nucleases, or CRISPR/Cas (Meyer et al. 2010; Wefers et al. 2013; Auer et al. 2014; Sommer et al. 2014), the NHEJ repair mechanisms occurred always and for each condition at a higher rate than HDR.

A transient cold shock applied to cells lines enhances the cleavage activity of ZFNs (Doyon et al. 2010) and TALE nucleases (Miller et al. 2011), due, at least in part, to an increase in accumulation of nuclease proteins (Doyon et al. 2010), but the effect on HDR was not analyzed. The assessment of this parameter allowed us to show a positive effect of a short or longer incubation at $30^{\circ} \mathrm{C}$ of injected embryos on the frequency of HDR events but not in the rate of NHEJ, suggesting a preferential repair by the former mechanism. This effect was more accentuated for the Hprt1.2 locus than for Rosa26. Moreover, no or slight effects were observed on viability and embryonic development of rat embryos. Although promising, additional experiments at other loci and in other species are necessary to confirm the generality of these observations.
In HDR strategies using ZFNs or TALE nucleases, donor DNA sequences can be linearized or supercoiled plasmids. In our four HDR insertions (Hprt1.1, Hprt1.2, Rosa26, and Ighm), HDR events were observed when donor DNA was delivered under a linear form, and when directly compared in the Hprt1.2 and Ighm loci, the circular form did not generate HDR events. In other studies using linear or circular DNA donors, the outcomes have been very variable. In the only previous study of HDR in rats using nucleases (ZFNs), both circular and linear forms generated HDR events (Cui et al. 2011; Brown et al. 2013). Using ZFNs in mice, two publications showed that both linear and circular DNA generated HDR (Meyer et al. 2010; Meyer et al. 2012), whereas another publication showed that only the linear, but not the circular form, could result in HDR (Hermann et al. 2012). In Drosophila, ZFNs or TALE nucleases induced HDR only using supercoiled plasmid donors (Beumer et al. 2008; Katsuyama et al. 2013). In rabbits, the linear form allowed obtention of HDR when using ZFNs (Flisikowska et al. 2011).

Compared to circular DNA, linear DNA has the potential disadvantage of being more prone to RI into the genome (Brinster et al. 1985). Our results show RI of linearized donor DNA (both the GFP expression cassette or human IGHM sequences) with frequencies of $0.62 \%$ to $1.71 \%$ of transferred embryos, close to the frequencies observed when linear DNA is microinjected to generate transgenic rats (Tesson et al. 2005). RI of circular donor DNA was also observed with frequencies of $0.95 \%$ and $0.72 \%$ for embryos transferred after Hprt1.2 or Ighm TALE nuclease injection, respectively. Therefore, in terms of transgene RI, there is not a significant disadvantage to the use of linear vs. circular donor DNA. Undesirable RI events could be separated from the desired modified allele by breeding (if unlinked to the target locus).

We observed that several of the Hprt1.1, Hprt1.2, Rosa26, and Ighm HDR-positive embryos or animals had concatemers. While few studies have analyzed the mechanisms of transgene concatemer formation, one recent one identified NHEJ as the main mechanism of concatamer formation (Dai et al. 2010). It is unclear why concatemers were observed at higher frequencies in the Hprt1 locus versus the Rosa26 or Ighm loci. Although transgenic animals with RI in concatemers are subject to gene silencing (Garrick et al. 1998), expression of GFP was equivalent in our rats harboring a profile with and without concatemers in the Rosa26 locus. This similar expression might be due to the insertion in a permissive locus versus RI in sites more prone to methylation. At the same

Figure 3. Targeted integration of a GFP cassette into the Rosa 26 locus. (A) (Upper) Diagram showing schematic representation of the rat Rosa26 locus, with the site of TALE nuclease action (vertical arrows) and of the targeting vector with the expression cassette (3142 bp) and the $5^{\prime}$ and $3^{\prime}$ homology arms (800 bp each). The homology arms are contiguous to the TALE nucleases' cleavage point. BstEll restriction sites are indicated. ( $A$ ) (Lower) Diagram showing schematic representation of the GFP cassette integration. For PCR in/out analysis, genomic DNAs were PCR-amplified with primers situated for the 5' side: upstream of the 5' HA arm (ROSA26-5outFor) and in the CAG promoter (5CAGpRev); and for the 3' side: in the BGHpA (3BGHpA-Up2) and downstream from the 3' HA arm (ROSA26-3out Rev). The position of each primer and the corresponding expected size of PCR products are indicated on the schematic knock-in Rosa26 locus. For Southern blot analysis, genomic DNA was digested with EcoRl and was probed with the homology arms' probe for Rosa26. Two bands at $9.2 \mathrm{~kb}$ and $2.2 \mathrm{~kb}$ are predicted for a correct HDR into the Rosa26 locus. (B) Flanking PCR analysis. Gels show the results analyzing the $5^{\prime}$ and the $3^{\prime}$ extremities of the expression cassette integration into the Rosa26 locus. A representative panel of nine founders is illustrated, showing expected bands of $1191 \mathrm{bp}$ using the first pair of primers (ROSA26-5outFor + 5CAGpRev), and of $1367 \mathrm{bp}$ using the second pair of primers (3BGHpA-Up2 + ROSA26-3outRev). The microinjection conditions in terms of mRNA and DNA concentrations as well as embryo incubation temperatures are above each animal. (C) Sequence comparison at the $5^{\prime}$ and $3^{\prime}$ junctions with wild-type genomic DNA and donor DNA sequences of two representative founders (2.1 and 10.2) and one representative F1 (8.4.1: offspring of founder 8.4). In donor DNA, the presence of the BstEll site is indicated (underlined). The start and the end of the expression cassette are colored in gray. (D) Two representative 8-d-old Rosa26 HDR rat pups (F1s of founder 8.4) and two wild-type littermates. GFP expression in adult tissues (liver, kidney, pancreas) of a Rosa26 HDR rat. Insets show tissues obtained from littermates negative for GFP PCR (wild type, WT). Magnification: $\times 100$. (E) GFP expression in leukocytes from different lines of Rosa26 HDR rats. FACS analysis of GFP expression in CD45+ leukocytes isolated from peripheral blood from four different lines of Rosa26 HDR adult rats (F1generation) and a wild-type littermate. (Upper) FACS patterns obtained from two F1 (an HDR GFP+ and a negative littermate) of founder 8.4. (Lower) Analysis of the level of GFP expression in the peripheral blood of offspring of four Rosa26 HDR founders using the mean fluorescence intensity of leukocytes. Each point represents one animal and the horizontal bars the mean and standard deviations. 
Table 1. Microinjection statistics for the Hprt1.1, Hprt 1.2, and Rosa26 loci

\begin{tabular}{|c|c|c|c|c|c|c|c|c|}
\hline $\begin{array}{l}\text { Target } \\
\text { locus }\end{array}$ & $\begin{array}{c}\text { Dose } \\
\text { mRNA/DNA } \\
(n g / \mu l)\end{array}$ & Temperature & $\begin{array}{l}\text { No. injected } \\
\text { eggs (\% viable } \\
\text { eggs) }\end{array}$ & $\begin{array}{l}\text { No. E15 (e) } \\
\text { or pups }(p) \\
(\%)^{\mathrm{a}}\end{array}$ & $\begin{array}{c}\text { No. of } \\
\text { GFP+ animals } \\
(\%)^{\mathrm{a}}\end{array}$ & 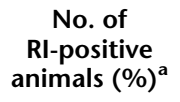 & 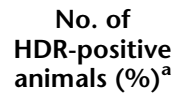 & $\begin{array}{c}\text { No. of } \\
\text { indel-positive } \\
\text { animals }(\%)^{\mathbf{a}}\end{array}$ \\
\hline Hprt1.1 & $\begin{array}{l}50+50 / 2 \\
20+20 / 2 \\
10+10 / 2\end{array}$ & $\begin{array}{l}37^{\circ} \mathrm{C} \\
37^{\circ} \mathrm{C} \\
37^{\circ} \mathrm{C}\end{array}$ & $\begin{array}{l}113(73.5) \\
209(78.5) \\
164(72.6)\end{array}$ & $\begin{array}{c}8 \mathrm{e}(13.3) \\
17 \mathrm{e}(10.7) \\
8 \mathrm{e}(8.2)\end{array}$ & $\begin{array}{l}0(0) \\
0(0) \\
1(1.02)\end{array}$ & $\begin{array}{l}0(0) \\
0(0) \\
0(0)\end{array}$ & $\begin{array}{l}0(0) \\
0(0) \\
1(1.02)\end{array}$ & $\begin{array}{l}1(1.67) \\
2(1.26) \\
2(2.04)\end{array}$ \\
\hline Hprt1.2 & $\begin{array}{c}20+20 / 2 \\
10+10 / 2 \\
10+10 / 2 \\
10+10 / 2 \\
5+5 / 2 \\
5+5 / 2 \\
5+5 / 2 \\
5+5 / 2 b \\
0 / 2\end{array}$ & $\begin{array}{c}37^{\circ} \mathrm{C} \\
37^{\circ} \mathrm{C} \\
37^{\circ} \mathrm{C} / 30^{\circ} \mathrm{C} \\
30^{\circ} \mathrm{C} \\
37^{\circ} \mathrm{C} \\
37^{\circ} \mathrm{C} / 30^{\circ} \mathrm{C} \\
30^{\circ} \mathrm{C} \\
30^{\circ} \mathrm{C} \\
30^{\circ} \mathrm{C}\end{array}$ & $\begin{array}{l}69(78.3) \\
258(72.1) \\
151(72.8) \\
163(82.8) \\
148(85.8) \\
158(93.7) \\
173(79.2) \\
159(71.1) \\
110(80)\end{array}$ & $\begin{array}{c}0(0) \\
32 \mathrm{e}(20.3) \\
19 \mathrm{e}(17.3) \\
22 \mathrm{e}(18.6) \\
33 \mathrm{e}(26.2) \\
42 \mathrm{e}(28.4) \\
35 \mathrm{e}(29.9) \\
25 \mathrm{e}(23.8) \\
38 \mathrm{e}(43.2)\end{array}$ & $\begin{array}{l}0(0) \\
1(0.63) \\
4(3.64) \\
6(5.08) \\
4(3.17) \\
6(4.05) \\
8(6.84) \\
1(0.95) \\
0(0)\end{array}$ & $\begin{array}{l}0(0) \\
0(0) \\
1(0.91) \\
3(2.54) \\
1(0.79) \\
2(1.35) \\
2(1.71) \\
1(0.95) \\
0(0)\end{array}$ & $\begin{array}{l}0(0) \\
1(0.63) \\
3(2.73) \\
3(2.54) \\
3(2.38) \\
4(2.70) \\
6(5.13) \\
0(0) \\
0(0)\end{array}$ & $\begin{array}{c}0(0) \\
15(9.49) \\
10(9.09) \\
6(5.08) \\
17(13.5) \\
24(16.2) \\
14(12) \\
4(3.81) \\
\text { na }\end{array}$ \\
\hline Rosa26 & $\begin{array}{c}20+20 / 2 \\
10+10 / 2 \\
5+5 / 2 \\
5+5 / 2 \\
5+5 / 2\end{array}$ & $\begin{array}{c}37^{\circ} \mathrm{C} \\
37^{\circ} \mathrm{C} \\
37^{\circ} \mathrm{C} \\
37^{\circ} \mathrm{C} / 30^{\circ} \mathrm{C} \\
30^{\circ} \mathrm{C}\end{array}$ & $\begin{array}{l}134(52.2) \\
180(76.7) \\
161(80.8) \\
158(68.4) \\
197(75.6)\end{array}$ & $\begin{array}{c}5 \mathrm{e}(10.6) \\
8 \mathrm{e}(8.8) \\
11 \mathrm{p}(9.2) \\
21 \mathrm{p}(19.4) \\
47 \mathrm{p}(31.5)\end{array}$ & $\begin{array}{l}0(0) \\
3(3.30) \\
2(1.67) \\
4(3.70) \\
1(0.67)\end{array}$ & $\begin{array}{l}0(0) \\
1(1.10) \\
0(0) \\
1(0.92) \\
1(0.67)\end{array}$ & $\begin{array}{l}0(0) \\
2(2.20) \\
2(1.67) \\
3(2.78) \\
0(0)\end{array}$ & $\begin{array}{l}1(2.13) \\
3(3.30) \\
5(4.17) \\
8(7.41) \\
6(4.03)\end{array}$ \\
\hline
\end{tabular}

Rat Hprt1.1, Hprt1.2, or Rosa26 TALE nucleases, as mRNA, were injected at different concentrations each in combination with $2 \mathrm{ng} / \mu$ l of donor DNA, both into the cytoplasm and into the male pronucleus. Donor DNA was injected either in a linear form with each of the three TALE nuclease pairs or in a circular form only with rat Hprt 1.2 TALE nucleases (see footnote b, below). Injected eggs were maintained under $5 \% \mathrm{CO}_{2}$ at $37^{\circ} \mathrm{C}$ for $3 \mathrm{~h}, 37^{\circ} \mathrm{C}$ for $1 \mathrm{~h}$, followed by $30^{\circ} \mathrm{C}$ for $2 \mathrm{~h}$, or $30^{\circ} \mathrm{C}$ for $3 \mathrm{~h}$ until reimplantation. Viability was evaluated after the culture period. Potential toxicity was also assessed by the number of day 15 embryos (E15) or of live pups obtained following the transfer of injected eggs. Percentage of the total transferred is indicated in parentheses. The numbers of $\mathrm{E} 15$ or live pups which have integrated the donor DNA sequence either by random integration (RI) or HDR integration (PCR positive both at the $5^{\prime}$ and $3^{\prime}$ ends) or which have indel mutations (T7 nuclease assay and sequencing) with no HDR are reported in the last four columns. (na) Not applicable. a Percentages indicated in parentheses correspond to the percentage of transferred embryos.

${ }^{b}$ Donor DNA was injected in a circular form in this condition.

time, expression levels in animals with concatemers were not higher compared to ones with one copy of the transgene, indicating that either some degree of gene silencing has occurred or that some of these extra copies were not intact. In order to improve the efficiency of single-copy transgene integration, concatemer formation may potentially be limited by in situ excision of donor sequences from plasmids. This could be achieved by flanking donor sequences on the injected plasmid by nuclease target sites. Such an approach has been tested in sea urchin and was found to favor HDR in sea urchin embryos injected with ZFNs (Ochiai et al. 2012). The use of a circular donor DNA with a nuclease site for in situ linearization but without any homology arms has also been shown recently to result in high-efficiency homology-independent knock-in of in vitro-transfected cells (Cristea et al. 2013; Maresca et al. 2013) and very recently in zebrafish (albeit concatemers were also observed using this strategy) (Auer et al. 2014). Future studies should compare the efficiency of targeted knock-in by HDR or NHEJ using this in vivo linearized donor DNA approach.

A parameter that can influence HDR following DNA cleavage by nucleases is the distance between the homology arms and the DNA break point. It has been found that the efficiency of gene conversion tracts after double-strand break repair by HDR in cells in vitro rapidly decreases with distance (100 bp) from the nuclease cleavage point (for review, see Johnson and Jasin 2001). In mice microinjected with TALE nucleases, oligonucleotide exchange preferentially occurred in proximity to the double-strand break (Wefers et al. 2013). This is an important point since it may be an obstacle to the exchange of endogenous sequences by new ones. Our results show that the efficiency of HDR using homology arms contiguous to the DNA break, such as in Hprt1.1, Hprt1.2, and Rosa26 loci $(1.02 \%, 0.63 \%$, and $2.2 \%$, respectively), were roughly comparable to that for the Ighm locus $(0.62 \%)$ with homology at $\sim 150$ bp from the DNA break point.

Transgenes expression can be influenced by the local environment (position effects) that can lead to transgene silencing or aberrant expression (Milot et al. 1996; Pedram et al. 2006; Gao et al. 2007; Williams et al. 2008). In contrast, targeted integration of DNA sequences into permissive loci, such as Hprt/Hprt1 (Bronson et al. 1996; Meek et al. 2010) or Rosa26 (Zambrowicz et al. 1997), by HDR in ES cells is usually chosen for expressing exogenous transgenes. Different ubiquitous promoters have been compared for levels of expression once inserted in the Rosa26 locus, and CAG was the strongest (Chen et al. 2011). Targeted insertion using nucleases has only been reported in the Rosa26 locus in mice embryos (Hermann et al. 2012). In accordance with these observations, all Rosa26 HDR rats analyzed expressed GFP ubiquitously. Thus, integration of other transgenes into the Hprt1 or Rosa26 locus via nuclease-stimulated HDR using the donor DNA constructs described in this study should avoid the phenomenon of positional effects and result in transgene expression following the pattern of expression of the promoter used.

This work was done with Sprague-Dawley rats, but other rat strains should also be suitable for HDR-directed genome editing using TALE nucleases, since others have generated knockout rats via NHEJ using TALE nucleases in other strains (Mashimo et al. 2013).

In summary, this report demonstrates the feasibility of TALE nucleases delivered into the zygote to generate rats with targeted, complex, and large transgene insertions. In particular, we targeted transgenes to high-value loci, such as Rosa26 or Hprt1, and replaced DNA sequences in an endogenous locus. This technique is a faster, cheaper, and easier alternative to ES cell manipulation (Dow and Lowe 2012). TALE nucleases now join ZFNs as having effected targeted transgene integration in vivo. CRISPR/Cas9 are even easier to 
Table 2. Genotype of all Hprt1.1-, Hprt1.2-, and Rosa26-targeted GFP-positive founders

\begin{tabular}{|c|c|c|c|c|c|c|c|c|}
\hline \multirow[b]{2}{*}{ Target } & \multirow[b]{2}{*}{ Donor DNA } & \multirow[b]{2}{*}{ ID/Sex } & \multirow[b]{2}{*}{ No. of alleles } & \multicolumn{2}{|c|}{ Allele KI } & \multirow[b]{2}{*}{ Status 2 nd allele } & \multirow[b]{2}{*}{$\mathbf{R I}$} & \multirow[b]{2}{*}{ Concatemers } \\
\hline & & & & $5^{\prime}$ insertion & $3^{\prime}$ insertion & & & \\
\hline Hprt1.1 & GFP & $37^{\circ} \mathrm{C}-13.1 / \mathrm{F}$ & 3 & + & + & $w t, \Delta 2 b p$ & - & + \\
\hline Hprt1.2 & GFP & $37^{\circ} \mathrm{C}-1.1 / \mathrm{F}$ & 2 & + & - & wt & - & + \\
\hline Hprt1.2 & GFP & $37^{\circ} \mathrm{C}-6.1 / \mathrm{F}$ & 2 & + & + & $\Delta 110 \mathrm{bp}$ & - & - \\
\hline Hprt1.2 & GFP & $37^{\circ} \mathrm{C}-9.6 / \mathrm{F}$ & 2 & + & + & $\Delta 41 \mathrm{bp}$ & - & + \\
\hline Hprt1.2 & GFP & $37^{\circ} \mathrm{C}-11.9 / \mathrm{F}$ & 2 & + & + & $\Delta 25 \mathrm{bp}$ & - & - \\
\hline Hprt1.2 & GFP & $37^{\circ} \mathrm{C}-12.2 / \mathrm{M}$ & Mosaic & + & + & Mosaic & - & + \\
\hline Hprt1.2 & GFP & $37^{\circ} \mathrm{C}-13.2 / \mathrm{F}$ & 2 & - & - & wt & + & + \\
\hline Hprt1.2 & GFP & $30^{\circ} \mathrm{C}-1.2 / \mathrm{F}$ & Mosaic & + & + & Mosaic & - & + \\
\hline Hprt1.2 & GFP & $30^{\circ} \mathrm{C}-2.2 / \mathrm{F}$ & 2 & + & + & $\Delta 9+\operatorname{lns} 1 \mathrm{bp}$ & - & - \\
\hline Hprt1.2 & GFP & $30^{\circ} \mathrm{C}-3.2 / \mathrm{M}$ & 1 & - & - & Large $\Delta$ & + & + \\
\hline Hprt1.2 & GFP & $30^{\circ} \mathrm{C}-3.4 / \mathrm{F}$ & 2 & + & + & $\Delta 16 \mathrm{bp}$ & - & + \\
\hline Hprt1.2 & GFP & $30^{\circ} \mathrm{C}-5.7 / \mathrm{F}$ & 2 & - & - & wt & + & - \\
\hline Hprt1.2 & GFP & $30^{\circ} \mathrm{C}-5.9 / \mathrm{F}$ & 2 & + & + & Large $\Delta$ & - & - \\
\hline Hprt1.2 & GFP & $30^{\circ} \mathrm{C}-6.4 / \mathrm{M}$ & 1 & - & - & Large $\Delta$ & + & + \\
\hline Hprt1.2 & GFP & $30^{\circ} \mathrm{C}-6.5 / \mathrm{F}$ & 2 & - & - & $\Delta 16, \Delta 22+\operatorname{Ins} 2 \mathrm{bp}$ & + & + \\
\hline Hprt1.2 & GFP & $30^{\circ} \mathrm{C}-7.3 / \mathrm{F}$ & 2 & + & + & Large $\Delta$ & - & + \\
\hline Hprt1.2 & GFP & $30^{\circ} \mathrm{C}-7.5 / \mathrm{F}$ & Mosaic & - & - & Mosaic & + & + \\
\hline Hprt1.2 & GFP & $30^{\circ} \mathrm{C}-7.8 / \mathrm{F}$ & 2 & - & - & Large $\Delta$ & + & - \\
\hline Hprt1.2 & GFP & $30^{\circ} \mathrm{C}-8.3 / \mathrm{F}$ & 2 & + & + & $\Delta 19 \mathrm{bp}$ & - & + \\
\hline Hprt1.2 & GFP & $30^{\circ} \mathrm{C}-9.7 / \mathrm{F}$ & 2 & + & + & wt & - & + \\
\hline Hprt1.2 & GFP & $30^{\circ} \mathrm{C}-10.2 / \mathrm{F}$ & 2 & + & + & $\Delta 29 \mathrm{bp}$ & - & + \\
\hline Hprt1.2 & GFP & $30^{\circ} \mathrm{C}-10.4 / \mathrm{F}$ & 2 & + & + & $\Delta 92 \mathrm{bp}$ & - & + \\
\hline Hprt1.2 & GFP & $37-30^{\circ} \mathrm{C}-4.4 / \mathrm{F}$ & 3 & + & + & $\Delta 19, \Delta 12+\operatorname{Ins} 2 \mathrm{bp}$ & - & + \\
\hline Hprt1.2 & GFP & $37-30^{\circ} \mathrm{C}-4.6 / \mathrm{F}$ & 2 & + & + & $\Delta 15 \mathrm{bp}$ & - & + \\
\hline Hprt1.2 & GFP & $37-30^{\circ} \mathrm{C}-5.1 / \mathrm{F}$ & 2 & - & - & $\Delta 50 \mathrm{bp}$ & + & + \\
\hline Hprt1.2 & GFP & $37-30^{\circ} \mathrm{C}-5.3 / \mathrm{F}$ & 2 & + & + & Large $\Delta$ & - & + \\
\hline Hprt1.2 & GFP & $37-30^{\circ} \mathrm{C}-7.2 / \mathrm{M}$ & Mosaic & + & + & Mosaic & - & + \\
\hline Hprt1.2 & GFP & $37-30^{\circ} \mathrm{C}-7.4 / \mathrm{F}$ & 2 & + & + & $\Delta 10 \mathrm{bp}$ & - & - \\
\hline Hprt1.2 & GFP & $37-30^{\circ} \mathrm{C}-9.5 / \mathrm{F}$ & 2 & - & - & wt & + & + \\
\hline Hprt1.2 & GFP & $37-30^{\circ} \mathrm{C}-10.2 / \mathrm{F}$ & 3 & + & + & $\mathrm{wt}, \Delta 1 \mathrm{bp}$ & - & + \\
\hline Hprt1.2 & GFP & $37-30^{\circ} \mathrm{C}-10.7 / \mathrm{F}$ & 2 & + & + & $\Delta 6 \mathrm{bp}$ & - & + \\
\hline Hprt1.2 & GFP & $37-30^{\circ} \mathrm{C}-10.8 / \mathrm{M}$ & Mosaic & - & - & Mosaic & + & + \\
\hline Hprt1.2 & GFP & $30^{\circ} \mathrm{C}$ circ $-4.1 / \mathrm{M}$ & 1 & - & - & Large $\Delta$ & + & - \\
\hline Rosa26 & GFP & $37^{\circ} \mathrm{C}-2.1 / \mathrm{F}$ & 2 & + & + & $\Delta 17 \mathrm{bp}$ & - & - \\
\hline Rosa26 & GFP & $37^{\circ} \mathrm{C}-3.1 / \mathrm{M}$ & 2 & + & + & $\bar{\Delta} 11 \mathrm{bp}$ & - & + \\
\hline Rosa26 & GFP & $37^{\circ} \mathrm{C}-5.3 / \mathrm{F}$ & 2 & - & - & $\mathrm{wt}, \Delta 1 \mathrm{bp}$ & + & nd \\
\hline Rosa26 & GFP & $37-30^{\circ} \mathrm{C}-7.1 / \mathrm{F}$ & 2 & - & - & wt & + & - \\
\hline Rosa26 & GFP & $37-30^{\circ} \mathrm{C}-8.4 / \mathrm{M}$ & Mosaic & + & + & Mosaic & - & - \\
\hline Rosa26 & GFP & $37-30^{\circ} \mathrm{C}-8.5 / \mathrm{M}$ & 2 & + & + & $\Delta 16 \mathrm{bp}$ & - & - \\
\hline Rosa26 & GFP & $37-30^{\circ} \mathrm{C}-9.1 / \mathrm{F}$ & 2 & + & + & Large $\Delta$ & - & - \\
\hline Rosa26 & GFP & $37^{\circ} \mathrm{C}-10.2 / \mathrm{F}$ & 2 & + & + & Large $\Delta$ & - & - \\
\hline Rosa26 & GFP & $37^{\circ} \mathrm{C}-12.5 / \mathrm{M}$ & 2 & + & + & $\Delta 8 \mathrm{bp}$ & - & + \\
\hline Rosa26 & GFP & $30^{\circ} \mathrm{C}-19.3 / \mathrm{F}$ & 2 & - & - & wt & + & + \\
\hline
\end{tabular}

ID refers to each day 15 embryo (E15) or live pup carrying an insertion of the transgene by HDR or RI. The culture conditions after microinjection are indicated for each Hprt1.1-, 1.2-, and Rosa26-positive animals. The Hprt1 locus is in the X chromosome. Some females with three X alleles or males with two $\mathrm{X}$ alleles are explained by mosaicism. As examples, female Hprt $1.1 \mathrm{GFP} 37^{\circ} \mathrm{C}-13.1 / \mathrm{F}$ had one $\mathrm{X}$ chromosome with wild-type sequences, a second one with a $\mathrm{KI}$, and a third one with a 2-bp deletion that originated in NHEJ. Others such as Hprt1.2 GFP 37-30 ${ }^{\circ} \mathrm{C}-4.4 / \mathrm{F}$ had one with a $\mathrm{KI}$ and two more with NHEJ mutations. Large $\Delta$ refers to either fetuses carrying deletions $>300 \mathrm{bp}$ in the PCR used to perform the T7 and sequencing analysis-most of these animals did not show amplification using primers amplifying a 700-bp sequence.

(Mosaic) Multiple undefined indels; (nd) not determined; (wt) wild-type allele.

generate and are an important new tool for genome editing, although more work is needed to fully evaluate potential off-target effects.

\section{Methods}

\section{Animals}

Sprague-Dawley (SD/Crl) rats were the only strain used and were sourced from the Charles River (L'Arbresle, France).

\section{Design and production of TALE nucleases}

TALE nucleases were produced as previously described (Piganeau et al. 2013; Auer et al. 2014) by the unit assembly method adapted from Huang et al. (2011) and are described in detail in the Supplemental Material.

\section{In vitro assay of TALE nucleases}

Each subunit of TALE nuclease plasmid was nucleofected into C6 cells (Sigma) and DNA analyzed by PCR with specific primers (Supplemental Table S2), followed by the T7 endonuclease I assay (Menoret et al. 2014), as detailed in the Supplemental Material.

\section{In vitro transcription of TALE nucleases mRNA}

TALE nuclease plasmids were in vitro transcribed, polyadenylated, purified, and used as described in detail in the Supplemental Material. 
A

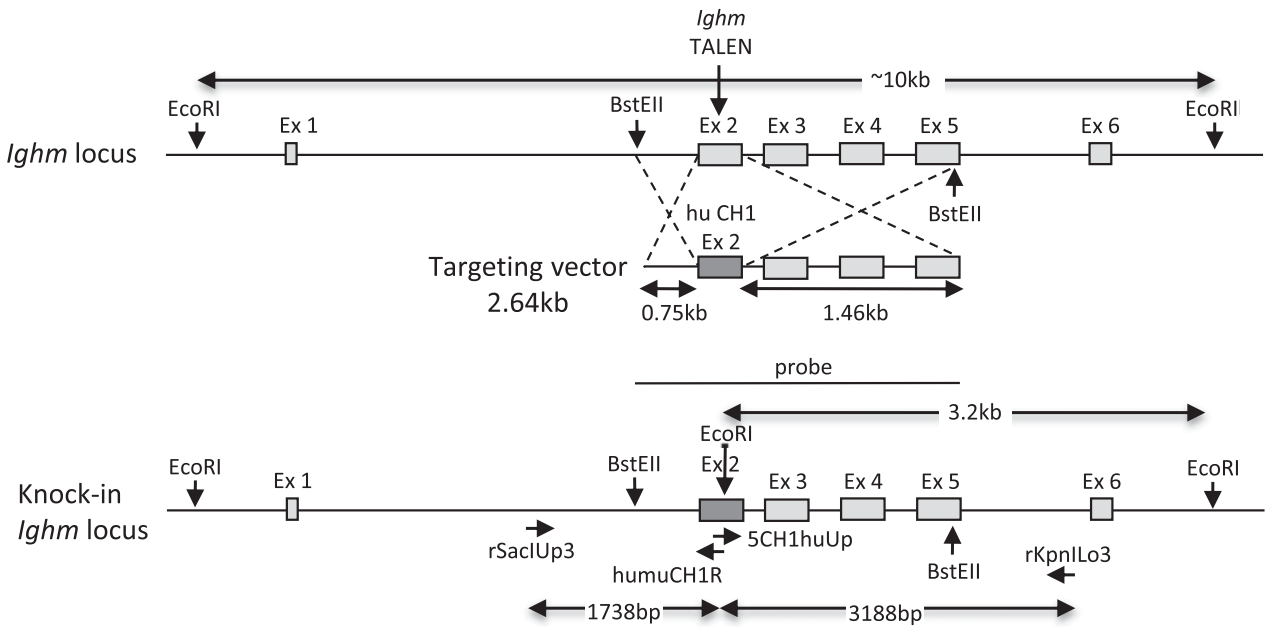

B

$5^{\prime}$ integration

3 ' integration

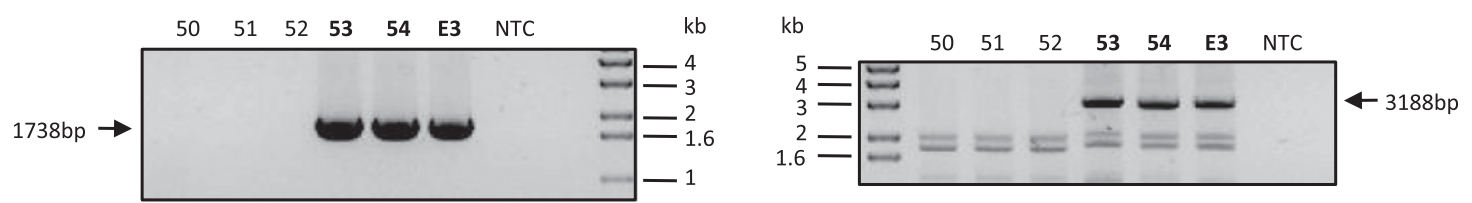

C

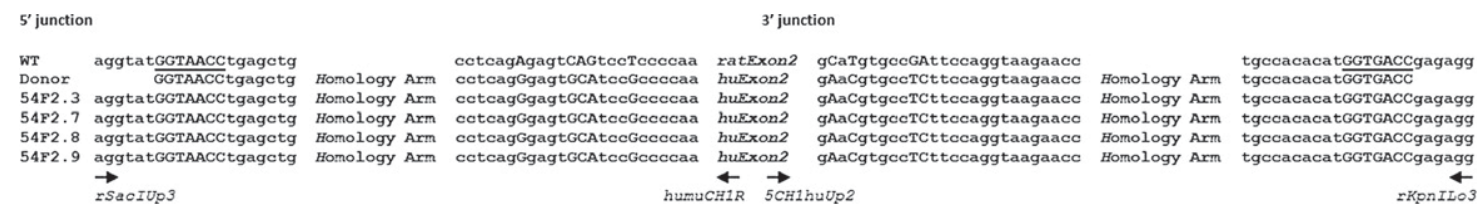

D

E
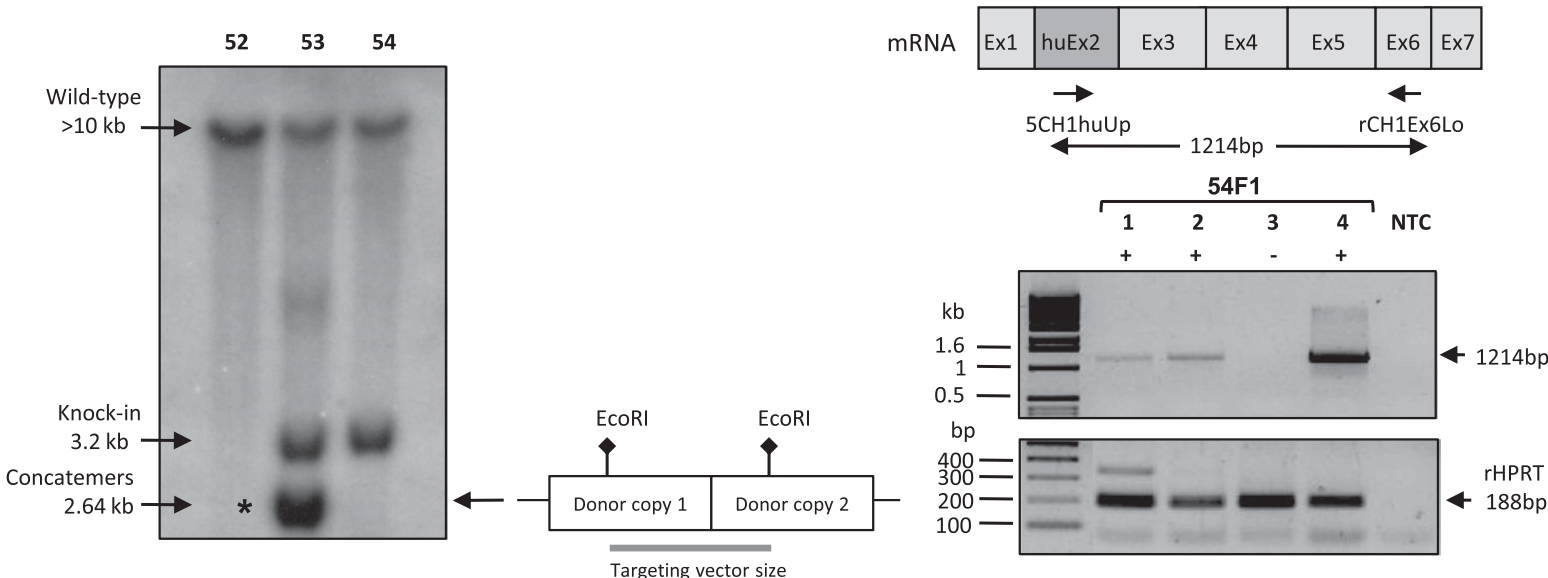

Figure 4. Targeted exon exchange into the rat Ighm locus. (A) (Upper) Diagrams showing schematic representations of the rat Ighm locus with the site of TALE nuclease action and of the targeting vector containing exon 2 of human IGHM flanked by $0.75-\mathrm{kb}-l o n g$ 5' and 1.46-kb-long 3' homology arms. (Lower) Diagram showing the integration by homologous recombination of the donor DNA sequence in the targeted locus, and the position of primers used for $5^{\prime}$ and $3^{\prime}$ junction PCRs. Integration in the $5^{\prime}$ and $3^{\prime}$ sides should generate fragments of $1738 \mathrm{bp}$ and $3188 \mathrm{bp}$, respectively. EcoRl is the restriction enzyme used in Southern blot analyses due to the presence of the EcoRl site in the human but not in the rat Ighm sequence. The probe used in Southern blot analyses is the targeting vector. In the case of homologous recombination events, a 3.2-kb band is expected. (B) The left and right gels show the results analyzing, respectively, the $5^{\prime}$ and $3^{\prime}$ extremity of DNA integration, using the pair of primers indicated in A. Three animals $(53,54$, and E3) showed a band of expected size (1738 bp in $5^{\prime}$ and 3188 bp in $3^{\prime}$ ends). (NTC) No template control. (C) Sequence comparison at the $5^{\prime}$ and $3^{\prime}$ junctions with wild-type genomic DNA and donor DNA sequences of four representative F2s (54F2.3, 54F2.7, 54F2. 8, and 54F2.9: F2 generation from animal 54). Exon exchange was confirmed at the BstEll site in $5^{\prime}$ and $3^{\prime}$ (underlined). (D) Southern blot analysis of founders for homologous recombination integration. Genomic DNA was digested with EcoRl and $10 \mu \mathrm{g}$ of DNA were loaded per lane. Blots were probed with the targeting sequence, as indicated in $A$. Arrows indicate bands of $10 \mathrm{~kb}$ and $3.2 \mathrm{~kb}$ corresponding to wild-type sequences and HDR sequences, respectively. An asterisk marks the presence of concatemers showing a band at $2.64 \mathrm{~kb}$ (the size of the transgene). The diagram at the right explains the expected size of the concatemers once linearized. Two animals (founders 53 and 54) harbor a HDR insertion, whereas no HDR event is observed in the third (animal 52). More than one copy of the donor DNA sequence is observed in animal 53. (E) (Upper) Diagrams showing a schematic representation of the mRNA sequence in HDR animals and the position of primers used for RT-PCR. A band of 1214 bp is expected. (Lower) Electrophoresis gel pictures show the presence of an amplified band of $1214 \mathrm{bp}$ in three animals born from the mating of the founder 54 (HDR) with a wild-type rat. The amplification of rat HPRT serves as a control. (NTC) No template control. 
Table 3. Microinjection statistics for the Ighm locus

\begin{tabular}{|c|c|c|c|c|c|c|c|}
\hline $\begin{array}{l}\text { Donor } \\
\text { DNA form }\end{array}$ & $\begin{array}{c}\text { Dose } \\
\text { mRNA/DNA } \\
(\mathrm{ng} / \mu \mathrm{l})\end{array}$ & Temperature & $\begin{array}{c}\text { No. injected } \\
\text { eggs (\% viable eggs) }\end{array}$ & $\begin{array}{c}\operatorname{No.} \text { E15 (e) } \\
\text { or pups }(p)(\%)^{a}\end{array}$ & $\begin{array}{c}\text { No. of } \\
\text { RI-positive } \\
\text { animals }(\%)^{\mathbf{a}}\end{array}$ & $\begin{array}{c}\text { No. of } \\
\text { HDR-positive } \\
\text { animals }(\%)^{\text {a }}\end{array}$ & $\begin{array}{c}\text { No. of } \\
\text { indel-positive } \\
\text { animals }(\%)^{\mathbf{a}}\end{array}$ \\
\hline Linear $^{b}$ & $5+5 / 10$ & $37^{\circ} \mathrm{C}$ & $1063(72.7)$ & $5 e-72 p(15.8)$ & $8(1.64)$ & $3(0.62)$ & 54 (11.1) \\
\hline Circular ${ }^{c}$ & $5+5 / 10$ & $37^{\circ} \mathrm{C}$ & $410(75.1)$ & $64 p(22.9)$ & $2(0.72)$ & $0(0)$ & $35(12.5)$ \\
\hline
\end{tabular}

Rat Ighm TALE nucleases, as mRNA, were injected at a concentration of $10 \mathrm{ng} / \mu \mathrm{l}$ in combination with $10 \mathrm{ng} / \mu \mathrm{l}$ of donor DNA, either in its linear form or in its circular form, both into the cytoplasm and into the male pronucleus. Injected eggs were maintained under $5 \% \mathrm{CO}_{2}$ at $37^{\circ} \mathrm{C}$ until reimplantation. Viability was evaluated after the culture period. Potential toxicity was also assessed by the number of day 15 embryos (E15) or of live pups obtained following the transfer of injected eggs. The numbers of E15 or live pups which have integrated the donor DNA sequence either by random integration (RI) or HDR integration (PCR positive both at the $5^{\prime}$ and $3^{\prime}$ ends) or which have indel mutations, are reported in the last three columns.

${ }^{a}$ Percentages indicated in parentheses correspond to the percentage of transferred embryos.

${ }^{b}$ Excised form.

'Supercoiled DNA.

\section{Targeting vector construction}

Plasmids donor sequences were based on the Brown Norway rat genomic sequence (assembly RGSC_3.4). For the Hprt1.1, Hprt1.2, and Rosa26 loci, donor sequences contained a CAG promotereGFP cDNA-BGHpA cassette flanked by two 800-bp homologous arms.

For the replacement of rat Ighm exon 2, we generated a plasmid containing human IGHM exon 2 flanked by rat sequence $5^{\prime}$ and $3^{\prime}$ homology arms ( $0.75 \mathrm{~kb}$ and $1.46 \mathrm{~kb}$, respectively).

The generation and use of these donor DNA sequences is described in detail in the Supplemental Material.

\section{Microinjection of rat one-cell embryos}

Fertilized one-cell-stage embryos were sequentially microinjected into the male pronucleus and into the cytoplasm. One-cell embryo collection and manipulation are described in the Supplemental Material.

\section{Analysis of NHEJ events}

Briefly, DNA fragments including the TALE nuclease targeted regions were PCR-amplified with a high-fidelity polymerase (Herculase II fusion polymerase) using specific primers (Supplemental Table S2). Mutations were analyzed using the T7 endonu- clease I assay (Menoret et al. 2013) and direct sequencing of PCR products.

\section{Analysis of targeted and RI of DNA donor sequences}

Donor DNA was amplified using the primer pairs for GFP. DNA from GFP+ animals was PCR-amplified with primers situated outside and inside of each extremity of the homology arms as described in detail in the Supplemental Material (Supplemental Table S2). Southern blots were done on genomic DNA digested by EcoRI for Hprt1.1, BamHI for Hprt1.2, and EcoRI for Rosa26.

\section{Analysis of GFP expression}

GFP expression was analyzed as described in detail in the Supplemental Material.

\section{Analysis of Ighm mRNA}

Analysis was performed on total RNA, DNase-treated, and PCRamplified using primers (Supplemental Table S2) and techniques described in the Supplemental Material section.

\section{Competing interest statement}

G.J.C. is a full-time employee of Sangamo BioSciences.

Table 4. Genotypes of all Ighm-positive founders analyzed at the target site

\begin{tabular}{|c|c|c|c|c|c|c|c|c|}
\hline \multirow[b]{2}{*}{ Target } & \multirow[b]{2}{*}{ Donor DNA } & \multirow[b]{2}{*}{ ID/Sex } & \multirow[b]{2}{*}{ No. of alleles } & \multicolumn{2}{|c|}{ Allele KI } & \multirow[b]{2}{*}{ Status 2nd allele } & \multirow[b]{2}{*}{ RI } & \multirow[b]{2}{*}{ Concatemers } \\
\hline & & & & $5^{\prime}$ insertion & $3^{\prime}$ insertion & & & \\
\hline $\mathrm{Ighm}$ & huCH1 & E3F & 2 & + & + & $\Delta 6 \mathrm{bp}$ & - & + \\
\hline $\mathrm{lghm}$ & huCH1 & $8 / \mathrm{F}$ & Mosaic & - & - & Mosaic & + & nd \\
\hline $\mathrm{lghm}$ & huCH1 & $44 / \mathrm{F}$ & 2 & - & - & $\Delta 84$ bp & + & - \\
\hline $\mathrm{lghm}$ & huCH1 & $49 / \mathrm{M}$ & 2 & - & - & $\Delta 27, \Delta 6 \mathrm{bp}$ & + & - \\
\hline $\mathrm{lghm}$ & huCH1 & $53 / \mathrm{M}$ & 2 & + & + & $\Delta 5 \mathrm{bp}$ & - & + \\
\hline $\mathrm{lghm}$ & huCH1 & $54 / \mathrm{M}$ & 2 & + & + & $\Delta 12$ bp & - & - \\
\hline $\mathrm{lghm}$ & huCH1 & $55 / \mathrm{F}$ & 2 & - & - & $\Delta 16, \Delta 16 \mathrm{bp}$ & + & - \\
\hline $\mathrm{lghm}$ & huCH1 & $56 / F$ & 2 & - & - & $\Delta 1, \Delta 1 \mathrm{bp}$ & + & - \\
\hline $\mathrm{lghm}$ & huCH1 & $63 / F$ & 2 & - & - & $\Delta 5, \Delta 5 \mathrm{bp}$ & + & + \\
\hline $\mathrm{lghm}$ & huCH1 & $68 / \mathrm{M}$ & Mosaic & - & - & Mosaic & + & + \\
\hline $\mathrm{lghm}$ & huCH1 & 69/M & 2 & - & - & nd & + & + \\
\hline $\mathrm{lghm}$ & huCH1 & Circ-81/F & 2 & - & - & nd & + & nd \\
\hline $\mathrm{lghm}$ & huCH1 & Circ-85/M & 2 & - & - & wt & + & nd \\
\hline
\end{tabular}

Circ-81/F and Circ-85/M are the two animals generated with the circular donor DNA whereas all the other animals were generated with the linear excised form. (Mosaic) Multiple undefined indels; (nd) not determined. 


\section{Acknowledgments}

Funding was provided by Région Pays de la Loire through Biogenouest, IBiSA program, Fondation Progreffe and TEFOR (Infrastructures d'Avenir of the French government). Sequencing experiments were performed by the integrative genomic facility of Nantes and Gregory J. Cost from Sangamo.

Author contributions: I.A., A.F., L.T., S.R., and S.M. conceived and designed the experiments. M.C., J.B.R., A.D.C., J.P.C., and C.G. performed the design, production, and in vitro assay of Hprt1 and Rosa26 TALE nucleases. G.J.C. designed and produced Ighm TALE nucleases and edited the manuscript. R.B. generated the IGHM DNA construct. L.T. performed in vitro transcription of TALE nucleases, built donor constructs, and carried out PCR and Southern blot analyses. V.T., R.T., and L.T. performed the T7 assay. S.R., S.M., and C.U. performed the microinjections. D.B. performed the statistical analyses. S.R. performed the FACS experiments and microscopy. S.R., L.T., and I.A. wrote the manuscript.

\section{References}

Auer TO, Duroure K, De Cian A, Concordet JP, Del Bene F. 2014. Highly efficient CRISPR/Cas9-mediated knock-in in zebrafish by homologyindependent DNA repair. Genome Res 24: 142-153.

Beumer KJ, Trautman JK, Bozas A, Liu JL, Rutter J, Gall JG, Carroll D. 2008 Efficient gene targeting in Drosophila by direct embryo injection with zinc-finger nucleases. Proc Natl Acad Sci 105: 19821-19826.

Brinster RL, Chen HY, Trumbauer ME, Yagle MK, Palmiter RD. 1985. Factors affecting the efficiency of introducing foreign DNA into mice by microinjecting eggs. Proc Natl Acad Sci 82: 4438-4442.

Brinster RL, Braun RE, Lo D, Avarbock MR, Oram F, Palmiter RD. 1989. Targeted correction of a major histocompatibility class II E $\alpha$ gene by DNA microinjected into mouse eggs. Proc Natl Acad Sci 86: 70877091.

Bronson SK, Plaehn EG, Kluckman KD, Hagaman JR, Maeda N, Smithies O. 1996. Single-copy transgenic mice with chosen-site integration. Proc Natl Acad Sci 93: 9067-9072.

Brown AJ, Fisher DA, Kouranova E, McCoy A, Forbes K, Wu Y, Henry R, Ji D, Chambers A, Warren J, et al. 2013. Whole-rat conditional gene knockout via genome editing. Nat Methods 10: 638-640.

Buehr M, Meek S, Blair K, Yang J, Ure J, Silva J, McLay R, Hall J, Ying QL, Smith A. 2008. Capture of authentic embryonic stem cells from rat blastocysts. Cell 135: 1287-1298.

Capecchi MR. 2005. Gene targeting in mice: functional analysis of the mammalian genome for the twenty-first century. Nat Rev Genet 6: 507-512.

Chen CM, Krohn J, Bhattacharya S, Davies B. 2011. A comparison of exogenous promoter activity at the ROSA26 locus using a PhiC31 integrase mediated cassette exchange approach in mouse ES cells. PLoS ONE 6: e23376.

Cristea S, Freyvert Y, Santiago Y, Holmes MC, Urnov FD, Gregory PD, Cost GJ. 2013. In vivo cleavage of transgene donors promotes nucleasemediated targeted integration. Biotechnol Bioeng 110: 871-880.

Cui X, Ji D, Fisher DA, Wu Y, Briner DM, Weinstein EJ. 2011. Targeted integration in rat and mouse embryos with zinc-finger nucleases. Nat Biotechnol 29: 64-67.

Dai J, Cui X, Zhu Z, Hu W. 2010. Non-homologous end joining plays a key role in transgene concatemer formation in transgenic zebrafish embryos. Int J Biol Sci 6: 756-768.

Dow LE, Lowe SW. 2012. Life in the fast lane: mammalian disease models in the genomics era. Cell 148: 1099-1109.

Doyon Y, Choi VM, Xia DF, Vo TD, Gregory PD, Holmes MC. 2010. Transient cold shock enhances zinc-finger nuclease-mediated gene disruption. Nat Methods 7: 459-460.

Flisikowska T, Thorey IS, Offner S, Ros F, Lifke V, Zeitler B, Rottmann O, Vincent A, Zhang L, Jenkins S, et al. 2011. Efficient immunoglobulin gene disruption and targeted replacement in rabbit using zinc finger nucleases. PLOS ONE 6: e21045.

Gao Q, Reynolds GE, Innes L, Pedram M, Jones E, Junabi M, Gao DW, Ricoul M, Sabatier L, Van Brocklin H, et al. 2007. Telomeric transgenes are silenced in adult mouse tissues and embryo fibroblasts but are expressed in embryonic stem cells. Stem Cells 25: 3085-3092.

Garrick D, Fiering S, Martin DI, Whitelaw E. 1998. Repeat-induced gene silencing in mammals. Nat Genet 18: 56-59.

Geurts AM, Cost GJ, Freyvert Y, Zeitler B, Miller JC, Choi VM, Jenkins SS, Wood A, Cui X, Meng X, et al. 2009. Knockout rats via embryo microinjection of zinc-finger nucleases. Science 325: 433.
Hermann M, Maeder ML, Rector K, Ruiz J, Becher B, Burki K, Khayter C, Aguzzi A, Joung JK, Buch T, et al. 2012. Evaluation of OPEN zinc finger nucleases for direct gene targeting of the ROSA26 locus in mouse embryos. PLOS ONE 7: e41796.

Huang P, Xiao A, Zhou M, Zhu Z, Lin S, Zhang B. 2011. Heritable gene targeting in zebrafish using customized TALENs. Nat Biotechnol 29: 699700 .

Jacob HJ. 1999. Functional genomics and rat models. Genome Res 9: 10131016.

Jacob HJ. 2010. The rat: a model used in biomedical research. Methods Mol Biol 597: 1-11.

Jacob HJ, Kwitek AE. 2002. Rat genetics: attaching physiology and pharmacology to the genome. Nat Rev Genet 3: 33-42.

Johnson RD, Jasin M. 2001. Double-strand-break-induced homologous recombination in mammalian cells. Biochem Soc Trans 29: 196-201.

Katsuyama T, Akmammedov A, Seimiya M, Hess SC, Sievers C, Paro R. 2013. An efficient strategy for TALEN-mediated genome engineering in Drosophila. Nucleic Acids Res 41: e163.

Kobayashi T, Kato-Itoh M, Yamaguchi T, Tamura C, Sanbo M, Hirabayashi M, Nakauchi H. 2012. Identification of rat Rosa26 locus enables generation of knock-in rat lines ubiquitously expressing tdTomato. Stem Cells Dev 21: 2981-2986.

Li P, Tong C, Mehrian-Shai R, Jia L, Wu N, Yan Y, Maxson RE, Schulze EN, Song H, Hsieh CL, et al. 2008. Germline competent embryonic stem cells derived from rat blastocysts. Cell 135: 1299-1310.

Li D, Qiu Z, Shao Y, Chen Y, Guan Y, Liu M, Li Y, Gao N, Wang L, Lu X, et al. 2013a. Heritable gene targeting in the mouse and rat using a CRISPR-Cas system. Nat Biotechnol 31: 681-683.

Li W, Teng F, Li T, Zhou Q. 2013b. Simultaneous generation and germline transmission of multiple gene mutations in rat using CRISPR-Cas systems. Nat Biotechnol 31: 684-686.

Maresca M, Lin VG, Guo N, Yang Y. 2013. Obligate ligation-gated recombination (ObLiGaRe): custom-designed nuclease-mediated targeted integration through nonhomologous end joining. Genome Res 23: $539-546$.

Mashimo T, Takizawa A, Voigt B, Yoshimi K, Hiai H, Kuramoto T, Serikawa T. 2010. Generation of knockout rats with X-linked severe combined immunodeficiency (X-SCID) using zinc-finger nucleases. PLOS ONE 5: e8870.

Mashimo T, Kaneko T, Sakuma T, Kobayashi J, Kunihiro Y, Voigt B, Yamamoto T, Serikawa T. 2013. Efficient gene targeting by TAL effector nucleases coinjected with exonucleases in zygotes. Sci Rep 3: 1253.

Meek S, Buehr M, Sutherland L, Thomson A, Mullins JJ, Smith AJ, Burdon T. 2010. Efficient gene targeting by homologous recombination in rat embryonic stem cells. PLOS ONE 5: e14225.

Menoret S, Fontaniere S, Jantz D, Tesson L, Thinard R, Remy S, Usal C, Ouisse LH, Fraichard A, Anegon I. 2013. Generation of Rag1-knockout immunodeficient rats and mice using engineered meganucleases. FASEB J 27: 703-711.

Menoret S, Tesson L, Remy S, Usal C, Thepenier V, Thinard R, Ouisse LH, De Cian A, Giovannangeli C, Concordet JP, et al. 2014. Gene targeting in rats using transcription activator-like effector nucleases. Methods doi: 10.1016/j.ymeth.2014.02.027.

Meyer M, de Angelis MH, Wurst W, Kuhn R. 2010. Gene targeting by homologous recombination in mouse zygotes mediated by zinc-finger nucleases. Proc Natl Acad Sci 107: 15022-15026.

Meyer M, Ortiz O, Hrabe de Angelis M, Wurst W, Kuhn R. 2012. Modeling disease mutations by gene targeting in one-cell mouse embryos. Proc Natl Acad Sci 109: 9354-9359.

Miller JC, Tan S, Qiao G, Barlow KA, Wang J, Xia DF, Meng X, Paschon DE, Leung E, Hinkley SJ, et al. 2011. A TALE nuclease architecture for efficient genome editing. Nat Biotechnol 29: 143-148.

Milot E, Strouboulis J, Trimborn T, Wijgerde M, de Boer E, Langeveld A, Tan-Un K, Vergeer W, Yannoutsos N, Grosveld F, et al. 1996. Heterochromatin effects on the frequency and duration of LCRmediated gene transcription. Cell 87: 105-114.

Ochiai H, Sakamoto N, Fujita K, Nishikawa M, Suzuki K, Matsuura S, Miyamoto T, Sakuma T, Shibata T, Yamamoto T. 2012. Zinc-finger nuclease-mediated targeted insertion of reporter genes for quantitative imaging of gene expression in sea urchin embryos. Proc Natl Acad Sci 109: $10915-10920$.

Panda SK, Wefers B, Ortiz O, Floss T, Schmid B, Haass C, Wurst W, Kuhn R. 2013. Highly efficient targeted mutagenesis in mice using TALENs. Genetics 195: 703-713.

Pedram M, Sprung CN, Gao Q, Lo AW, Reynolds GE, Murnane JP. 2006. Telomere position effect and silencing of transgenes near telomeres in the mouse. Mol Cell Biol 26: 1865-1878.

Piganeau M, Ghezraoui H, De Cian A, Guittat L, Tomishima M, Perrouault L, Rene O, Katibah GE, Zhang L, Holmes MC, et al. 2013. Cancer translocations in human cells induced by zinc finger and TALE nucleases. Genome Res 23: 1182-1193.

\section{Genome Research}


Ponce de Leon V, Merillat AM, Tesson L, Anegon I, Hummler E. 2014 Generation of TALEN-mediated GR ${ }^{\mathrm{dim}}$ knock-in rats by homologous recombination. PLOS ONE 9: e88146.

Segal DJ, Meckler JF. 2013. Genome engineering at the dawn of the golden age. Annu Rev Genomics Hum Genet 14: 135-158.

Sommer D, Peters A, Wirtz T, Mai M, Ackermann J, Thabet Y, Schmidt J, Weighardt H, Wunderlich FT, Degen J, et al. 2014. Efficient genome engineering by targeted homologous recombination in mouse embryos using transcription activator-like effector nucleases. Nat Commun 5: 3045 .

Tesson L, Cozzi J, Menoret S, Remy S, Usal C, Fraichard A, Anegon I. 2005. Transgenic modifications of the rat genome. Transgenic Res 14: 531-546.

Tesson L, Usal C, Menoret S, Leung E, Niles BJ, Remy S, Santiago Y, Vincent AI, Meng X, Zhang L, et al. 2011. Knockout rats generated by embryo microinjection of TALENs. Nat Biotechnol 29: 695-696.

Tong C, Li P, Wu NL, Yan Y, Ying QL. 2010. Production of p53 gene knockout rats by homologous recombination in embryonic stem cells. Nature 467: 211-213.

Tong C, Huang G, Ashton C, Wu H, Yan H, Ying QL. 2012. Rapid and costeffective gene targeting in rat embryonic stem cells by TALENs. J Genet Genomics 39: 275-280.

Wang H, Hu YC, Markoulaki S, Welstead GG, Cheng AW, Shivalila CS, Pyntikova T, Dadon DB, Voytas DF, Bogdanove AJ, et al. 2013. TALEN- mediated editing of the mouse Y chromosome. Nat Biotechnol 31: 530532 .

Wefers B, Meyer M, Ortiz O, Hrabe de Angelis M, Hansen J, Wurst W, Kuhn R. 2013. Direct production of mouse disease models by embryo microinjection of TALENs and oligodeoxynucleotides. Proc Natl Acad Sci 110: $3782-3787$.

Williams A, Harker N, Ktistaki E, Veiga-Fernandes H, Roderick K, Tolaini M, Norton T, Williams K, Kioussis D. 2008. Position effect variegation and imprinting of transgenes in lymphocytes. Nucleic Acids Res 36: 2320-2329.

Yamamoto S, Nakata M, Sasada R, Ooshima Y, Yano T, Shinozawa T, Tsukimi Y, Takeyama M, Matsumoto Y, Hashimoto T. 2012. Derivation of rat embryonic stem cells and generation of protease-activated receptor-2 knockout rats. Transgenic Res 21: 743-755.

Zambrowicz BP, Imamoto A, Fiering S, Herzenberg LA, Kerr WG, Soriano P. 1997. Disruption of overlapping transcripts in the ROSA $\beta$ geo 26 gene trap strain leads to widespread expression of $\beta$-galactosidase in mouse embryos and hematopoietic cells. Proc Natl Acad Sci 94: 3789_ 3794.

Zheng S, Geghman K, Shenoy S, Li C. 2012. Retake the center stage-new development of rat genetics. J Genet Genomics 39: 261-268.

Received December 20, 2013; accepted in revised form April 16, 2014. 


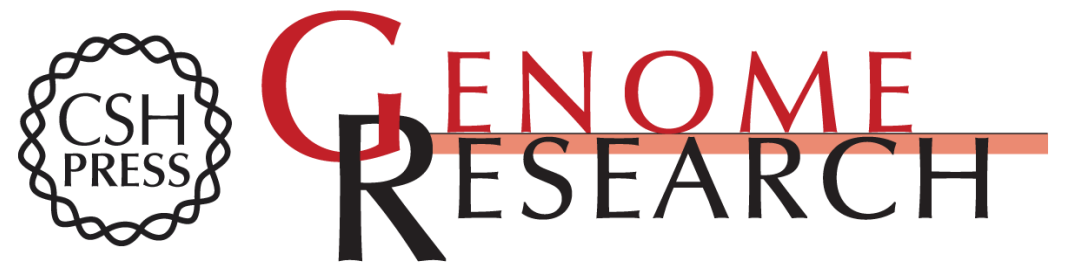

\section{Efficient gene targeting by homology-directed repair in rat zygotes using TALE nucleases}

Séverine Remy, Laurent Tesson, Séverine Menoret, et al.

Genome Res. 2014 24: 1371-1383 originally published online July 2, 2014

Access the most recent version at doi:10.1101/gr.171538.113

Supplemental Material

References

Creative

Commons

License

Email Alerting

Service
http://genome.cshlp.org/content/suppl/2014/06/10/gr.171538.113.DC1

This article cites 56 articles, 16 of which can be accessed free at: http://genome.cshlp.org/content/24/8/1371.full.html\#ref-list-1

This article is distributed exclusively by Cold Spring Harbor Laboratory Press for the first six months after the full-issue publication date (see

http://genome.cshlp.org/site/misc/terms.xhtml). After six months, it is available under a Creative Commons License (Attribution-NonCommercial 4.0 International), as described at http://creativecommons.org/licenses/by-nc/4.0/.

Receive free email alerts when new articles cite this article - sign up in the box at the top right corner of the article or click here.

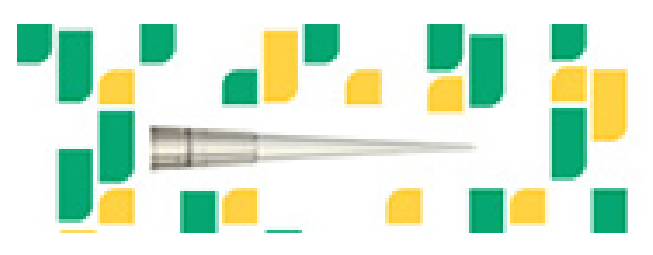

Focused on your science.

Jコగ

SCIENTIFIC

saos or seisnes

To subscribe to Genome Research go to:

https://genome.cshlp.org/subscriptions 